\title{
Demystifying the Citizen Soldier
}

Raphael S. Cohen 
For more information on this publication, visit www.rand.org/t/RR1141

Library of Congress Cataloging-in-Publication Data is available for this publication.

ISBN: 978-0-8330-9163-5

Published by the RAND Corporation, Santa Monica, Calif.

(C) Copyright 2015 RAND Corporation

RAND $^{\circledR}$ is a registered trademark.

\section{Limited Print and Electronic Distribution Rights}

This document and trademark(s) contained herein are protected by law. This representation of RAND intellectual property is provided for noncommercial use only. Unauthorized posting of this publication online is prohibited. Permission is given to duplicate this document for personal use only, as long as it is unaltered and complete. Permission is required from RAND to reproduce, or reuse in another form, any of its research documents for commercial use. For information on reprint and linking permissions, please visit www.rand.org/pubs/permissions.html.

The RAND Corporation is a research organization that develops solutions to public policy challenges to help make communities throughout the world safer and more secure, healthier and more prosperous. RAND is nonprofit, nonpartisan, and committed to the public interest.

RAND's publications do not necessarily reflect the opinions of its research clients and sponsors.

\section{Support RAND}

Make a tax-deductible charitable contribution at www.rand.org/giving/contribute

www.rand.org 


\section{Preface}

In his General Ronald R. Fogleman Award-winning essay, Air National Guard Colonel Mark Meyer claimed, "With a strong National Guard and its membership of citizen soldiers, national security policy will remain consistent with the will of the people - the ultimate requirement of our democracy." ${ }^{1}$ For Meyer and others, the Guard's importance to American society runs far deeper than the missions it conducts or the money it saves the U.S. Department of Defense. These advocates argue that the Guard historically has served as the linchpin for American national security, prevented the United States from fighting controversial foreign wars, andmost important of all - embodied the ideals of "citizen soldier." While most of today's debate about the active-reserve component mix rightly focuses on cost or utility, these historical and sociological claims also need to be critically evaluated.

This analysis, conducted in RAND Project AIR FORCE's Strategy and Doctrine Program, evaluates these claims and examines the Guard's

- centrality to American national security

- ability to prevent the United States from fighting controversial foreign wars

- embodiment of the ideals of the citizen soldier.

\section{RAND Project AIR FORCE}

RAND Project AIR FORCE (PAF), a division of the RAND Corporation, is the U.S. Air Force's federally funded research and development center for studies and analyses. PAF provides the Air Force with independent analyses of policy alternatives affecting the development, employment, combat readiness, and support of current and future air, space, and cyber forces. Research is conducted in four programs: Force Modernization and Employment; Manpower, Personnel, and Training; Resource Management; and Strategy and Doctrine. The research reported here was prepared under contract FA7014-06-C-0001.

Additional information about PAF is available on our website:

www.rand.org/paf/

\footnotetext{
${ }^{1}$ Mark P. Meyer, "The National Guard Citizen-Soldier: The Linkage Between Responsible National Security Policy and the Will of the People," Maxwell Air Force Base, Ala.: Air War College, Maxwell Paper No. 6, November 1996, pp. 1-2, 30.
} 


\section{Contents}

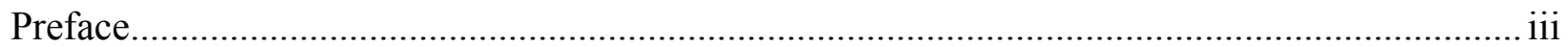

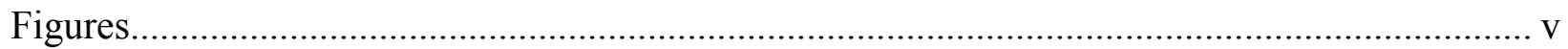

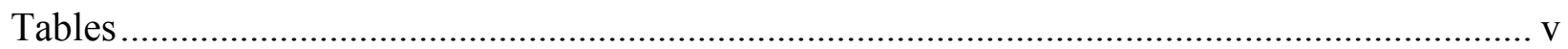

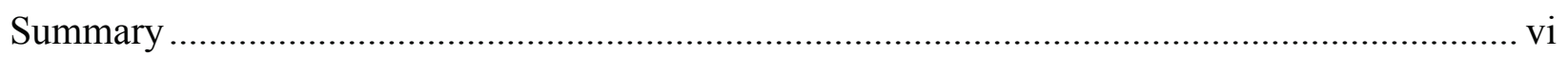

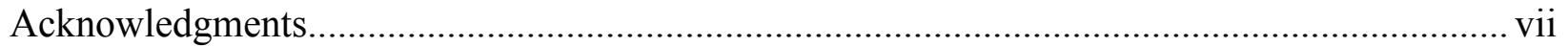

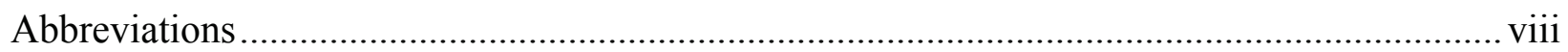

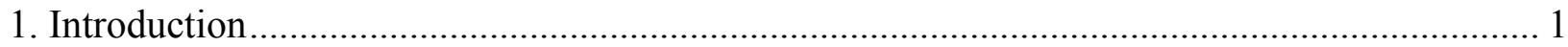

2. Defining and Evaluating the Mystique of the Citizen Soldier ............................................. 3

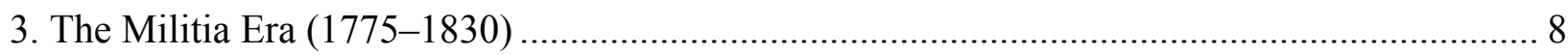

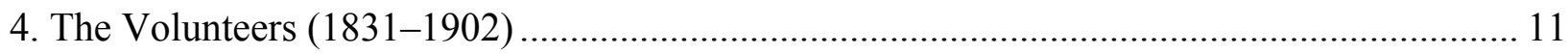

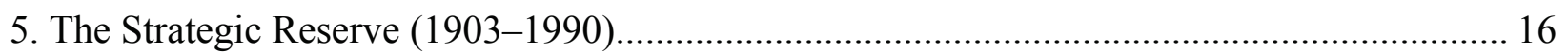

6. The Move to an Operational Reserve (1991-Present) ........................................................ 22

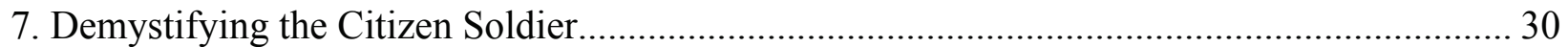

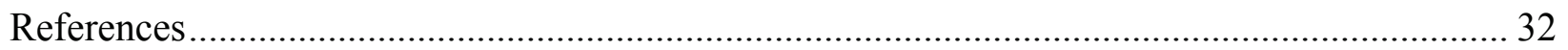




\section{Figures}

Figure 1. National Guard Participation in Overseas Conflicts (Strategic Reserve Period) .......... 18

Figure 2. National Guard Participation in Overseas Conflicts (Operational Reserve Period)...... 23

Figure 3. Service Members Deployed to Iraq and Afghanistan, 2001-2008........................... 25

\section{Tables}

Table 1. Claims About the National Guard and Their Observable Implications......................... 7

Table 2. Full-Time Support for the National Guard ................................................................ 28

Table 3. Assessment of the Claims About the National Guard ................................................ 30

Table 4. Trends in the Citizen Soldier Construct.................................................................... 31 


\section{Summary}

The National Guard is often portrayed as the modern heir to the colonial militia and as retaining at least three of the latter's three defining attributes - a key instrument of American national security, a check on federal power, and home of today's "citizen soldiers." this assertion prompts three questions. First, how has the National Guard transformed from a militia to the institution it is today? Second, what does the term "citizen soldier" mean? And third, how have the militia and the National Guard embodied these three attributes at various points during history? Arguably, the answers to these questions shape more than our understanding of the National Guard; they also play to broader debates about civil-military relations and the intersection of military and civilians in American society today.

This report explores how the term citizen soldier has been defined in academic literature - as compulsory, universal, legitimate service by civilians - and then looks at how the National Guard has evinced these attributes at various periods in its history. Since the United States' founding, the militia - and later, the National Guard - slowly evolved into an increasingly formidable warfighting force and increasingly important tool for national security. This evolution, however, has come at the expense of two other attributes of the colonial militiaserving as a check on federal power and filling its ranks with citizen soldiers. The report concludes that there are inherent and increasing tensions among being a warfighting force, serving as a check on federal power, and embodying the ideals of a citizen soldier, and it is not clear that the Guard - or any other force for that matter - can fully reconcile them.

Ultimately, the Guard's transformation from citizen soldiers to a professional force may very well be inevitable and is likely a positive development for American national security. It is, however, important to realize that this trend is occurring, to demystify the citizen soldier, and to see the force for what it is.

\footnotetext{
${ }^{1}$ For example, see National Guard Bureau, 2015 National Guard Bureau Posture Statement, Washington, D.C., 2015, pp. 7, 9, 11, 15, 20, 58; Gus Hargett, President, National Guard Association of the United States, testimony delivered before the Reserve Forces Policy Board's Task Group, July 16, 2013, pp. 2-3; and Michael D. Doubler, The National Guard and Reserve: A Reference Handbook, Westport, Conn.: Praeger Security International, 2008, p. 1.
} 


\section{Acknowledgments}

I would like to thank RAND Project AIR FORCE for funding this project, and Dr. Paula Thornhill for her invaluable guidance and critiques of previous drafts. Dr. Sean Zeigler and Dr. Gian Gentile provided critical help with the research phase. Mr. Dick Anderegg, Dr. Lisa Harrington, and Dr. Richard Kohn provided thoughtful critiques of an earlier draft and shaped both the final product and my thinking on these issues immeasurably. Brigadier General Timothy Cathcart also provided a thoughtful critique of an earlier draft. In addition, the attendees of a presentation of this paper hosted by the Secretary of the Air Force-Chief of Staff of the Air Force Executive Action Group provided important feedback. Jane Siegel, Kimbria McCarty, Amanda Hagerman-Thompson, and Kari Thyne helped with formatting and editing the document and navigating the RAND publication processes. 


\section{Abbreviations}

9/11 terrorist attacks of September 11, 2001

ANG

Air National Guard

FTS

full-time support

PAF

Project AIR FORCE 


\section{Introduction}

In February 2012, the U.S. Air Force - under pressure from Congress to reduce spendingannounced plans to cut 3,900 airmen from the active component force, 900 from the Air Force Reserve, and 5,100 from the Air National Guard (ANG), and to retire 500 aging aircraftprimarily from the ANG. ${ }^{1}$ The proposal sparked an uproar from the National Guard Association of the United States, the National Governors Association, and the newly created Council of Governors. The National Governors Association even "took the unprecedented step of asking Congress to reject the Air Force's budget out of hand.", By April, Secretary of Defense Leon Panetta had restored 2,200 Guard positions but even this was insufficient to quell Guard supporters in Congress and in the National Governors Association. ${ }^{3}$

Today, a similarly heated debate is occurring within the U.S. Army over who should control that service's AH-64 Apache helicopters - and, more broadly, who should absorb the coming budget cuts forced upon the service by sequestration. ${ }^{4}$ Stepping back from the specifics, these debates demonstrate the Guard's powerful presence in American politics and society at large. Indeed, in its coverage of the ANG's budget battle, the New York Times quipped, "In combat zones, National Guard units generally take their orders from active-duty commanders. Not so in Washington.",5

Explanations for the Guard's widespread appeal fall broadly into three categories. First, there are political reasons: The Guard's constitutional mandate, dual federal-state nature, and geographical dispersion make it uniquely positioned to respond directly to states' needs - from natural disaster relief to supplementary law enforcement - and, consequently, to have a strong influence on congressional decisionmaking. Second, there are economic and utilitarian arguments: The Guard can provide a cost-effective adjunct to the active component, ${ }^{6}$ and it may

\footnotetext{
1 James Dao, “Air National Guard Lobbies Successfully Against Budget Cuts,” New York Times, April 24, 2012.

2 John Grady, "What a Difference Two Wars Make: No Battles Between Army, Guard and Reserve," Breaking Defense, April 2, 2012.

${ }^{3}$ Brian Everstine, "Guard Compromise Not Enough for Lawmakers," Air Force Times, April 24, 2012.

${ }^{4}$ Sydney Freedberg, Jr., "National Guard Commanders Rise in Revolt Against Active Army; MG Rossi Questions Guard Combat Role," Breaking Defense, March 11, 2014 b.

${ }^{5}$ Dao, 2012.

${ }^{6}$ For example, the National Guard Association of the United States, the Guard's semiofficial lobbying arm, proclaims, "The numbers speak for themselves. For 11 percent of the Army budget, the Army National Guard provides 32 percent of the Army's total personnel and 40 percent of its operating force. For 6 percent of the Air Force budget, the Air National Guard provides 19 percent of the Air Force's total personnel and 30-40 percent of the fighter, tanker and airlift capacity." National Guard Association of the United States, Legislative Strategic Plan, $113^{\text {th }}$ Congress, undated-b, p. 5. Similarly, the National Guard's Posture Statement repeatedly emphasizes its costeffectiveness. National Guard Bureau, 2015 National Guard Bureau Posture Statement, Washington, D.C., 2015, pp. 7, 9, 25, 39, 51, 61 .
} 
attract skills found in the civilian world that are not easily retained in the military. ${ }^{7}$ Finally, there are historical and sociological explanations, which are often mentioned but rarely evaluated: The Guard - which claims the mantle of modern heir to the colonial militia — remains deeply rooted in American tradition and plays a critical role in civil-military relations. ${ }^{8}$ While much of the analytical effort directed toward the Guard rightly focuses on economic and utilitarian arguments, these latter claims also deserve attention. ${ }^{9}$

Over the next six chapters, I examine the historical evolution and sociological role of the National Guard. First, I analyze three key claims about the National Guard: that it is the principal instrument of American national security, that it prevents the United States from fighting controversial foreign wars, and that it embodies the attributes of the "citizen soldier." I then examine each of these claims during the militia era (from the founding of the United States until 1830, when the enrolled militia system began to break down), the volunteer period (from 1831 until the Dick Act of 1903, when the federal government began to assert more authority over the Guard in exchange for increased funding), the strategic reserve (lasting roughly until the end of the Cold War), and the operational reserve (from the end of the Cold War until today, when the Guard began to be used regularly in overseas operations). I conclude with the implications of the study's core findings for today's policy debates: Two of these historical and sociological claims are true-with caveats. Only the idea that the National Guard and militia prevented the United States from fighting foreign wars does not appear to have a firm empirical base. More important, embedded in these three claims is an inherent tension that has only increased over time, and it is not clear that the Guard - or any force, for that matter - can fully reconcile them.

\footnotetext{
${ }^{7}$ For example, see Commission on the National Guard and Reserves, Transforming the National Guard and Reserves into a 21st-Century Operational Force, final report to Congress and the Secretary of Defense, January 31, 2008, p. 9; and John Nagl and Travis Sharp, An Indispensable Force: Investing in America's National Guard and Reserves, Washington, D.C.: Center for a New American Security, September 2010, pp. 14-15. For Dempsey and Hagel arguing that the National Guard and the reserve component at large should complement the capabilities in the active component, see U.S. Department of Defense, Quadrennial Defense Review 2014, Washington, D.C., March 4, 2014, p. 60; and Chuck Hagel, U.S. Secretary of Defense, "FY15 Budget Preview," press briefing, February 24, 2014.

8 For example, see National Guard, About the Army National Guard, undated; Gus Hargett, President, National Guard Association of the United States, testimony delivered before the Reserve Forces Policy Board's Task Group, July 16, 2013, pp. 2-3; and Michael D. Doubler, The National Guard and Reserve: A Reference Handbook, Westport, Conn.: Praeger Security International, 2008, p. 1.

${ }^{9}$ For example, see Albert A. Robbert, Costs of Flying Units in Air Force Active and Reserve Components, Santa Monica, Calif.: RAND Corporation, TR-1275-AF, 2013; and Joshua Klimas, Richard E. Darilek, Caroline Baxter, James Dryden, et al., Assessing the Army's Active-Reserve Component Force Mix, Santa Monica, Calif.: RAND Corporation, RR-417-1-A, 2014. For official studies, see Commission on National Guard and Reserves, 2008; and Reserve Forces Policy Board, "Eliminating Major Gaps in DoD Data on the Fully-Burdened and Life-Cycle Cost of Military Personnel: Cost Elements Should be Mandated by Policy,” Falls Church, Va., January 14, 2013.
} 


\section{Defining and Evaluating the Mystique of the Citizen Soldier}

The National Guard's mystique starts with a seemingly straightforward historical claim: Even before its founding, the Guard served as the linchpin in U.S. national defense. Indeed, the Army National Guard claims that the Guard is the "the oldest component of the United States armed forces," tracing its roots to the first militia regiment formed in Massachusetts in $1636 .{ }^{1}$ National Guard Association President Gus Hargett said, "If you look back in history, you'll find a nation that relied on citizen soldiers to protect and defend our country for several hundred years." 2 Similarly, National Guard officer and historian Michael D. Doubler argues that the Guard's role in "defending the nation is as old as America itself" and that it played "an indispensable role in defeating the nation's enemies," throughout its history and particularly in the 20th century. ${ }^{3}$ Even the Guard's symbol — a militiaman resolutely grasping a musketevokes images of the Minutemen who defended the nascent American state at Lexington and Concord and have been there for the country ever since.

Air Force Chief of Staff General Ronald Fogleman - ironically, a former active-component airman and not a Guardsman - attributes even more importance to the militia and the Guard's role in the history of American defense. In a 1995 speech, he asserted, "a fundamental precept of our American military tradition is that the United States of America is a militia nation." militia nation, he meant, "in peacetime, the U.S. maintained a small full-time military that was augmented during wartime with state militia and eventually, the National Guard. Once a conflict was over, the nation rapidly demobilized and returned to its reliance on militia or Guard forces." More recently, Fogleman claimed that the militia model provides a construct for how to fight wars in the future and solve current defense budget shortfalls. In a 2012 article, he argued that "we should return to our historic roots as a militia nation." ${ }^{6}$ More specifically, he said, "we should return to the constitutional construct for our military and the days when we maintained a smaller standing military and a robust militia."7 Ultimately, Fogleman's characterization suggests a testable hypothesis: If the United States is, indeed, a "militia nation," the majority—or

\footnotetext{
${ }^{1}$ National Guard, undated.

2 Hargett, 2013, p. 3.

${ }^{3}$ Doubler, 2008, p. 1 .

4 Ronald R. Fogleman, "Fundamental to Military Tradition: America, Militia Nation," speech to the National Guard Association of the United States Convention, Cleveland, Ohio, September 7, 1995.

${ }^{5}$ Fogleman, 1995.

${ }^{6}$ Ronald R. Fogleman, "Going Back to the Future: Militia Model Could Cut U.S. Expenditures," Defense News, January 16, 2012.

${ }^{7}$ Fogleman, 2012.
} 
at least the plurality — of the combat power used to fight U.S. wars should come from the militia — or, later, the National Guard.

According to its proponents, the Guard defended the United States in another sense as wellby preventing it from fighting wars in the first place. As former Maine Army National Guard Adjutant General James Campbell said, "A less often discussed, but nonetheless critical, function of this organizational method was recognized by the founders of the nation-a small standing regular force and reliance for the preponderance of our security on the militia acts as a significant brake on executive power, requiring Congress either to authorize a federalization of the militia or vote for an expansion of regular forces to mobilize the nation for engagement in a major conflict." "Indeed, some active component officers also accepted this logic. Most notably, after the Vietnam War, Army Chief of Staff Creighton Abrams designed the service to rely more heavily on the reserve component (both Army Reserve and Army National Guard) to prevent a repeat of the highly unpopular war and "to maintain a clear linkage between the employment of the army and the engagement of public support for military operations." "This, in turn, leads to a second testable claim: If the militia and National Guard - and, in latter times, the reserve component at large - performed this function, there should be a historical record of this structure preventing the United States from fighting wars.

The Guard's mystique runs deeper than a storied lineage or its role as a check on federal power; rather, it is bound up in the concept of the citizen soldier. This idea pervades the Guard's public statements. In his recent testimony to the Senate Armed Services Committee, Chief of the National Guard Bureau General Frank Grass repeatedly referred to the "citizen-soldiers and airmen" of the Guard, rather than simply as soldiers, airmen, or Guardsmen. ${ }^{10}$ The label implies that the Guard forms the crucial bridge between the military and the rest of American society. In fact, Grass asserted that the National Guard's "377-year legacy as an operational force [is] deeply engrained within the foundation of American strength and values.",11

Some suggest that the Guard serves as the essential link between the American public and military. In his General Ronald R. Fogleman Award-winning essay, Air National Guard Colonel Mark Meyer claimed, "With a strong National Guard and its membership of citizen-soldiers, national security policy will remain consistent with the will of the people - the ultimate requirement of our democracy," and "without the existence or use of the National Guard, the nation treads dangerously toward inconsistency between national security policy and the will of

\footnotetext{
8 James Campbell, “The National Guard as a Strategic Hedge," Parameters, Vol. 44, No. 1, Spring 2014, p. 97.

9 Alice R. Buchalter and Seth Elan, Historical Attempts to Reorganize the Reserve Components, Washington, D.C.: Federal Research Division, Library of Congress, October 2007, p. 15.

${ }^{10}$ Frank J. Grass, “Army Total Force Mix,” statement before the Senate Armed Services Committee, April 8, 2014.

${ }^{11}$ Grass, 2014, p. 1.
} 
the people."12 Hargett argued similarly: "Living and working in over 3,000 communities across the country, the National Guard is the face of our U.S. military. To lose this direct militarycivilian connection is to lose our nation's long-standing tradition of unquestionable support for our armed forces." $" 13$ Even some active component officers have echoed this claim. Strategist and author Colonel Harry Summers said in the 1970s that the United States should increase its reliance on the reserves so that "the citizen-soldiers of the National Guard and the Reserve would serve as a bridge between the American people."14

Evaluating this last claim - the National Guard's role in American society and democracyproves a more complicated task than evaluating the other two assertions. After all, the concept of "citizen soldiers and airmen" is rather nebulous and ill defined. All American servicemenactive or reserve - either are citizens already or on the path to earning citizenship. Other organizations, aside from the National Guard, also claim the mantle of citizen soldiers. For example, the Virginia Military Institute claims to prepare "cadets to become citizen-soldiers who will serve their country and communities," since about half of their graduates choose military careers while many others pursue civilian public service careers. ${ }^{15}$ Similarly, the U.S. Marine Corps' recruiting website explicitly states, "We develop quality citizens" under a section labeled "our purpose is our promise." "What, then, makes the National Guard unique?

Academic work often associates citizen soldiers more with conscription-based militaries than with the reserve component. Indeed, military sociologist Morris Janowitz used the term in a 1979 essay to characterize the draft-era military — not the National Guard. ${ }^{17}$ Similarly, Eliot Cohen did not answer whether the citizen solder label should apply to reservists, but argued that "the term seems archaic, even quaint" in the 21 st century. ${ }^{18}$ Historian Barry Strauss claimed that while "the idea of the citizen-soldier remains alive" across all the components (not just the National Guard), in practice, "the American citizen-soldier is a far less common figure than he was in the era of conscription." 19 Finally (but perhaps most interestingly), during the height of the Iraq and Afghanistan Wars, sociologist Charles Moskos proposed reinvigorating the citizen soldier concept — not by expanding the National Guard, but by creating a new category of short-

\footnotetext{
${ }^{12}$ Mark P. Meyer, The National Guard Citizen-Soldier: The Linkage between Responsible National Security Policy and the Will of the People, Maxwell Air Force Base, Ala.: Air War College, Maxwell Paper No. 6, November 1996, pp. 1-2, 30 .

13 Hargett, 2013, p. 17.

${ }^{14}$ Charles E. Heller, The New Military Strategy and Its Impact on the Reserve Component, Carlisle, Pa.: Strategic Studies Institute, United States Army War College, 1991, p. 26.

${ }^{15}$ Virginia Military Institute, Citizen-Soldier, undated.

${ }^{16}$ U.S. Marine Corps, Our Purpose, undated.

${ }^{17}$ Morris Janowitz, “The Citizen Soldier and National Service,” Air University Review, December 1979.

${ }^{18}$ Eliot A. Cohen, “Twilight of the Citizen-Soldier," Parameters, Summer 2001, p. 23.

19 Barry Strauss, "Reflections on the Citizen-Soldier," Parameters, 2003, p. 67.
} 
term active-duty enlistments. He concluded, "The citizen-soldier proposed here harkens to our nation's militia tradition of national defense. ${ }^{20}$ In other words, while Janowitz, Cohen, Strauss, and Moskos all seem open to the idea that Guardsmen, in fact, are citizen soldiers, they indicate that other forms of military service may be a better fit.

Even if these works do not directly tackle the Guard's role as citizen soldiers, they lend form to this amorphous concept. Janowitz defines the term based on three dimensions. Military service must be obligatory (compulsory service fulfilling part of one's duties as a citizen), universal (reflective of the nation as a whole, not just one segment of the population) and have legitimacy by democratic standards (or strong popular support). ${ }^{21}$ Most scholars accept Janowitz's definition. Cohen, for example, also uses a three-part definition: Like Janowitz, he ascribes the obligatory and universal characteristics to citizen soldiers, stating, "in the case of the true citizensoldier, military service is either an obligation imposed by the state or the result of mobilization for some pressing cause," and the "true army of citizen-soldiers represents the state." ${ }^{22}$ Cohen, however, substitutes Janowitz's "democratic-legitimacy" characteristic for another dimension: Instead of standing armies staffed by full-time soldiers, "the true citizen-soldier's identity is fundamentally civilian."23

To a varying degree, the National Guard's own definition of what it means to be a citizen soldier reflects these four traits as well. For example, Doubler also emphasizes the obligatory attribute, saying "citizens have a civic duty and moral obligation to defend their local community and the nation from foreign invaders and domestic threats" ${ }^{24}$ (emphasis added). In addressing the universal and democratic legitimacy qualities, he suggests that citizen soldiers come from "the very mainstream of society" and "constitute an important link that binds together the government, the military and the people. ${ }^{, 25}$ Like Cohen, Doubler highlights the civilian aspect of citizen soldiers. "In times of crisis, citizen-soldiers set aside their personal pursuits and private lives, don the uniform for a temporary period, perform their duties, and return to civilian life."26

Perhaps, this last quality - a fundamentally civilian identity — is the most important of the four attributes. Indeed, in his classic History of the Militia and the National Guard, John Mahon defines citizen soldier as "a person who is primarily a civilian, acting, in war or peace, as a soldier. ${ }^{27}$ The Cohen-Mahon-Doubler definition, however, prompts the question of what it means to be primarily or fundamentally a civilian. On a basic level, Cohen and Doubler's

\footnotetext{
${ }^{20}$ Charles Moskos, “A New Concept of the Citizen-Soldier," Orbis, 2005, p. 675.

${ }^{21}$ Morris Janowitz, “The Citizen Soldier and National Service," Air University Review, December 1979.

${ }^{22}$ Cohen, 2001, pp. 23-24.

${ }^{23}$ Cohen, 2001, p. 23.

${ }^{24}$ Doubler, 2008, p. 1.

${ }^{25}$ Doubler, 2008, p. 1.

${ }^{26}$ Doubler, 2008, p. 1.

${ }^{27}$ John K. Mahon, History of the Militia and the National Guard, New York: MacMillan, 1983, p. 4.
} 
definition implies that soldiering is a temporary occupation for citizen soldiers; these individuals do not intend to make a career of military service. Mahon's definition suggests that soldiering is a part-time profession and that a majority of one's day is spent outside the military. On a deeper, if more amorphous level, a citizen soldier's identity and outlook on the world should more closely reflect those of the broader civilian population, rather those of the military. ${ }^{28}$

In sum, the historical and sociological underpinnings of the National Guard's mystique can be reduced to three testable propositions, each of which should have clear observable implications in the historical record (see Table 1). First, the Guard has been the principal instrument of American national security, by providing a plurality of combat forces used to fight America's wars. Second, the Guard has — by its dual federal-state nature — prevented the United States from fighting controversial foreign wars. Third, the Guard captures the essence of the American citizen soldier by embodying Janowitz and Cohen's four traits: obligatory, universal, "legitimate" service performed largely by self-identifying civilians rather than active-component soldiers. The question, of course, is the extent to which the evidence fits with these claims. With that, we turn to the National Guard's historical evolution.

Table 1. Claims About the National Guard and Their Observable Implications

\begin{tabular}{|c|c|c|}
\hline & Claims & Observable Implication \\
\hline \multirow{2}{*}{ Historical } & Provided the principal instrument of American security & Provides a plurality of the combat power \\
\hline & Prevented the United States from fighting wars & Wars not fought \\
\hline \multirow{4}{*}{$\begin{array}{l}\text { Sociological } \\
\text { (citizen } \\
\text { soldier) }\end{array}$} & Obligatory & Compulsory service \\
\hline & Universal & Reflective of the general American population \\
\hline & Legitimate & Well regarded by the American population \\
\hline & Civilian & Temporary (noncareer) and part-time service \\
\hline
\end{tabular}

\footnotetext{
${ }^{28}$ Doubler alludes to this argument: "Citizen-soldiers bring to the military the fundamental and diverse societal values of entrepreneurship, innovation, pragmatism, risk taking and problem solving, traits that are not always associated with career soldiers.” Doubler, 2008, p. 1.
} 


\section{The Militia Era (1775-1830)}

At first glance, the American military history of the late 18th and early 19th centuries provides the strongest evidence for the first hypothesis: that the National Guard —or in its earlier incarnation, the militia - served as the principal instrument of American national security. As then-Chairman of the Joint Chief of Staff General Richard Myers said in his 2004 introduction to the Joint Forces Quarterly's issue on the reserve component, "The New England militia fought at Lexington and Concord, the first engagements of the Revolutionary War, in April 1775. It won the Army's first battle streamer at Fort Ticonderoga in May 1775. It wasn't until a month later that the Continental Congress officially established the Continental Army.""

A militia-based force also had serious limitations. Indeed, as historian John Shy notes, General George Washington "never ceased complaining about his militia—about their undependability, their indiscipline, their cowardice under fire." ${ }^{2}$ Washington himself summed it up: "To place any dependence upon the militia is assuredly resting upon a broken staff." 3 As political scientist Ronald Krebs noted, some of the founding fathers turned to the militia because it was the best option available, not because it was the optimal solution. John Adams, for example, believed that "not more than a regiment 'of the meanest, idlest, most intemperate, and worthless' would have signed up for the war's duration." "Eventually, the United States needed to form a more unified Continental Army (molded by a Prussian military officer, no less) before it could win the Revolutionary War.

Moreover, as the decades drew on, American politicians increasingly became convinced that the militia system could not serve as the principal instrument for American national security in the future. One reason was that the militia system proved unreliable during crises. During the 1786 Shay's Rebellion, for example, 800 militiamen - sympathetic to the rebels - refused to put down the uprising. ${ }^{5}$ Later, during the War of 1812, mobilizing the militia proved "cumbersome and ineffective" and even when mobilized, militiamen occasionally refused orders — such as to

\footnotetext{
${ }^{1}$ Richard Myers, Chairman, Joint Chiefs of Staff, “A Note from the Chairman,” Joint Forces Quarterly, Vol. 36, 2004, p. 4.

2 John Shy, A People Numerous and Armed: Reflections on the Military Struggle for the American Independence, Revised Edition, Ann Arbor, Mich.: University of Michigan Press, 1990, p. 237.

${ }^{3}$ Heller, 1991, p. 5.

${ }^{4}$ Ronald R. Krebs, "The Citizen-Soldier Tradition in the United States: Has Its Demise Been Greatly Exaggerated?" Armed Forces and Society, Vol. 36, No. 1, 2009, p. 156. For a similar argument, see Richard H. Kohn, Eagle and Sword: The Federalists and the Creation of the Military Establishment in America, 1783-1802, New York: The Free Press, 1975.

${ }^{5}$ Mahon, 1983, p. 47.
} 
cross into Canada, which extended beyond their mandate. ${ }^{6}$ Another reason politicians turned away from the militia system was that it proved difficult to manage and costly to outfit. Many militiamen could not afford to equip themselves and federal funds (some $\$ 200,000$ in 1808) were insufficient to do so (with some estimates of the full costs ranging up to $\$ 50$ million). ${ }^{7}$ Consequently, by 1830 , the War Department's appropriation for the militia equipped only 12,500 men out of an estimated pool of $1-2$ million eligible men. ${ }^{8}$ As a result, the early republic looked for alternative military solutions.

The second historical claim - that the militia system prevented the United States from fighting wars - proves harder to test, if only because it requires trying to prove a negative referring to wars not fought. But insofar as there is evidence, the record shows little validity to this claim. While the militia system proved unwieldy, the United States fought wars nonetheless - most notably, the American Revolution and the War of 1812, but also a host of frontier skirmishes. When the militia system proved unworkable, the United States looked for alternative options - such as employing a small regular Army and requesting unrestricted volunteers for individual campaigns.

Finally, the third proposition - that the militia embodied true citizen soldiers-has, perhaps, the firmest evidentiary base. Service in the militia was compulsory — on paper, at least, though not always in practice. While the 1792 Militia Act required all white men ages 18 to 45 to enroll in their local militia, "obligatory service fell into obsolescence over the succeeding decades, notwithstanding the letter of the law." "Historian Richard Kohn remarks that even in colonial times, universal enrollment into militia was less a system and more a concept of "a people in arms to ward off an invader," with a number of exceptions. ${ }^{10}$

The militia was both universal (at least for its day) and composed of true civilians. In theory, the unorganized militia included 719,499 in 1811, approximately 10 percent of the population, although the fighting force was considerably smaller in actuality. ${ }^{11}$ It excluded key demographics - notably women and slaves - but included large swaths of the rest of society. And the force was certainly civilian. As historian Jim Dan Hill notes, even the generals and colonels on the rolls "were undoubtedly just as reluctant about assuming the field duty

\footnotetext{
${ }^{6}$ For more about General Stephen Van Resselaer's aborted raid on October 12, 1812, see Mahon, 1983, p. 68. Also see Abbott A. Brayton, “American Reserve Policies Since World War II," Military Affairs, Vol. 36, No. 4, December 1972, pp. 139-144; and John J. Esch, "Our Second Line-The National Guard," The North American Review, Vol. 177, No. 561, August 1903, p. 291.

${ }^{7}$ Mahon, 1983, p. 66.

${ }^{8}$ Mahon, 1983, p. 83.

${ }^{9}$ Krebs, 2009, p. 160. See, also, Frederick P. Todd, “Our National Guard: An Introduction to Its History,” Military Affairs, Vol. 5, No. 3, 1941, p. 156.

${ }^{10}$ Kohn, 1975, p. 7.

${ }^{11}$ Jim Dan Hill, The Minute Man in Peace and War: A History of the National Guard, Harrisburg, Pa.: The Stackpole Company, 1964, p. 11. The population of the United States in 1810 was estimated at 7,239,000.
} 
implications of such ranks and titles as most the men on their mass rosters were reluctant to buy their own arms, uniforms and ammunition." 12

As for the legitimacy of the early American militia, many suggest that this was one of the primary strengths of the militia system, although it is hard to say for certain without public opinion data. Despite his misgiving about their military utility, George Washington declared in 1791 that "the militia is certainly an object of primary importance, whether viewed in reference to the national security to the satisfaction the community, or the preservation of order."13 Perhaps, the reason behind Washington's statement is the militia's place in society. Shy, for example, argues that one of the militia's main virtues was giving Americans "a political education conducted by military means," forcing an apathetic majority to take sides, thereby "nullif(ying) every British attempt to impose royal authority short of using massive armed force." $" 14$

Ultimately, the actual militia of the founding era differs from that of popular imagination. Despite the image of heroic Minutemen, the militia was not as central to American national security as some contend, and while the militia system proved an inefficient means of mobilizing men and resources, it did not prevent the United States from going to war. Still, the early militia largely fulfilled the last of the three claims: they were - for better or worse - citizen soldiers.

\footnotetext{
12 Hill, 1964, p. 11.

${ }^{13}$ Esch, 1903, p. 290.

${ }^{14}$ Shy, 1990, p. 366-367.
} 


\section{The Volunteers (1831-1902)}

In 1831, Delaware abolished its militia system. Between 1844 and 1851, Maine, Ohio, Vermont, Connecticut, New York, Missouri, and New Hampshire followed suit. ${ }^{1}$ Other statesincluding New Jersey, Iowa, Michigan, and California - either exempted their young men from service or removed the threat of prison for failing to pay the militia fine. ${ }^{2}$ In its stead, a new militia system based on optional participation came increasingly into vogue - volunteer companies. Volunteer companies in the United States date back to well before the founding: Boston's Ancient and Honorable Artillery Company was founded in $1638 .{ }^{3}$ As the enrolled or compulsory militia declined, these voluntary companies grew in importance and, over the next seven decades, became an increasingly organized, formal institution, eventually evolving into the National Guard of today.

With the rise of volunteer companies, some suggest that the first claim - that the militia provided the principal instrument of American military power-remained true. According to some accounts, the Mexican-American War was "largely fought and won by militia regiments from the Southern and Western States enlisting as volunteers." ${ }^{4}$ During the Civil War, the Union and Confederate armies consisted mostly of state-raised regiments, similar to the National Guard's structure. And the state-based "volunteer" forces ultimately contributed more than 223,000 soldiers and officers to the Spanish-American War, composing the vast majority of the Army's overall end strength. ${ }^{5}$

On closer examination, however, most of these volunteers were not members of the volunteer companies. On January 1, 1861, just prior to the Civil War, the volunteer strength of the Northern state militias numbered 41,190 personnel spread throughout 781 companies. ${ }^{6}$ Abraham Lincoln exhausted the North's supply of militiamen when he called for 75,000 men early on in

\footnotetext{
${ }^{1}$ Mahon, 1983, p. 83.

2 Mahon, 1983, p. 83.

${ }^{3}$ Marcus Cunliffe, Soldiers and Civilians: The Martial Spirit in America 1775-1865, Boston, Mass.: Little, Brown and Company, 1968, p. 217.

${ }^{4}$ Esch, 1903, p. 291.

${ }^{5}$ For grand total figures, see Adjutant General's Office, Statistical Exhibit of Strength of Volunteer Forces Called Into Service During the War With Spain; with Losses From All Causes, Washington, D.C.: Government Printing Office, 1899; reprinted online by the U.S. Army Center of Military History Historical Resources Branch, SpanishAmerican War: Volunteer Forces, undated. By way of comparison, on November 29, 1898, the Army had in total 178,000 officers and men - only 63,000 of them regulars. Graham A. Cosmas, An Army for Empire: The United States Army in the Spanish-American War, College Station, Texas: Texas A\&M University Press, 1998, p. 304.

6 Todd, 1941, p. 153.
} 
the war. ${ }^{7}$ Consequently, the Union Army largely consisted of men with "no previous training in the school of the soldier" "who either volunteered or later were drafted "under special statutes"not as militia. ${ }^{9}$ The same phenomenon also occurred in other American wars. For example, the Spanish-American War volunteers were "in reality a mass of undrilled civilians commanded by National Guard officers and stiffened by a thin cadre of old militiamen." "That is to say, while the United States turned to citizen soldiers to fill out the Army's ranks during the 19th century, this often did not mean turning to the militia (or later, the National Guard).

Moreover, the senior leadership often came from the regular Army. For example, while the Civil War was fought mostly by state-based regiments, regular Army officers led most of these troops. Generals Ulysses S. Grant, William Tecumseh Sherman, Robert E. Lee, James Longstreet, and Thomas "Stonewall” Jackson - and many others - all graduated from the U.S. Military Academy at West Point and spent much (although not all) of their careers as full-time soldiers. Similarly, during the Spanish American War, President William McKinley appointed 26 major generals and 102 brigadiers for the "volunteer" companies, most of whom (19 and 66 respectively) came from the regular army. ${ }^{11}$

While the volunteer companies did not provide the principal tool for fighting wars, they increasingly took on an active role at home and with it, a new name - the National Guard. New York first used the label "National Guards" for its militia in 1824, in honor of Gilbert du Motier, the Marquis de Lafayette, when he visited the city (Lafayette had commanded the French National Guards in 1789). ${ }^{12}$ The term picked up popularity after the Civil War. In 1869, New Jersey became one of the first states to switch its militia's title to the "National Guard." than three decades later, in 1896, only three states retained the name "militia," with the rest opting for the term "National Guard." 14 The term "militia" hung on in certain areas: The War Department still used the term "organized militia" to refer to the National Guard at least as late

\footnotetext{
${ }^{7}$ Esch, 1903, p. 291; and Todd, 1941, p. 153. Mahon notes that "the militia rolls in the North showed 2,471,377 men," but goes on to say that these dated to 1827 , so, in reality, states often could only raise 1 or 2 percent of their paper strength. Mahon, 1983, p. 97-98.

${ }^{8}$ Todd, 1941, p. 153.

${ }^{9}$ Elbridge Colby and James F. Glass, "The Legal Status of the National Guard," The Virginia Law Review, Vol. 29, No. 7, May 1943, p. 846.

${ }^{10}$ Cosmas, 1998, p. 119. Mahon estimates that 40 percent of the volunteer force had no previous drill experience. That said, since he estimates the National Guard's size at the start of hostilities at 114,000 strong, but the total number of volunteers at 223,000, there are reasons to question this estimate. Mahon, 1983, pp. 128, 125, 133.

${ }^{11}$ Mahon, 1983, p. 128.

12 Colby and Glass, 1943, p. 842.

${ }^{13}$ Colby and Glass, 1943, p. 842.

${ }^{14}$ Colby and Glass, 1943, p. 842.
} 
as 1912, and the "Militia Bureau" officially changed its name to the "National Guard Bureau" in 1933. ${ }^{15}$

The shift of labels away from militia to National Guard was more than just semantics. Formed around old volunteer companies and combining the remnants of the old militia, the National Guard became the instruments state governors used to respond to domestic unrest. The task was very much in keeping with the intended function of militias as outlined in the Constitution - to "execute the Laws of the Union, suppress Insurrections, and repel Invasions." 16 The new incarnation, however, gave state governors a more capable tool to perform these tasks, and from end of the Civil War to 1906, the Guard was called out 481 times - mostly to handle race conflicts, political disputes, and industrial disputes; guard prisoners; enforce state laws; and perform a variety of other law-and-order functions. ${ }^{17}$

The National Guard also became increasingly important for coastal defense during this period. Particularly in the latter half of the 19th century, with the rise of steel warships powered by steam engines, concern grew about the vulnerability of coastal areas to long-range offshore bombardment. Given the regular army's small size, the, Secretary of War William Endicott saw the Guard as a solution. To this end, Congress increased federal support to the Guard to $\$ 400,000$ in 1887 - marking one of the first significant boosts in funding for the Guard since 1808 and reaffirming the Guard's role in homeland defense. ${ }^{18}$

The second claim - that the militia prevented the United States from fighting controversial foreign wars - proved increasingly untrue. To be sure, some advocates for the militia (and later the Guard) protested fighting foreign wars. For example, writing in The North American Review in 1900, Charles Clark lambasted the "perverted public sentiment" that called for using the Guard abroad. "It is wholly unreasonable to expect them [the National Guard] to sacrifice their business interests, and inflict hardships upon their creditors and families by abandoning business to go with their organizations to different points in America or foreign countries," he wrote. ${ }^{20}$ Indeed, through the end of the 19th century, there was no procedure for mobilizing the militia during wartime, nor a clear legal authority for the President to deploy the Guard abroad. ${ }^{21}$ As a result, late in the century, some in the regular Army wanted to create an entirely new force to better allow the United States to fight wars abroad. Civil War General and postwar military

\footnotetext{
${ }^{15}$ Colby and Glass, 1943, pp. 840, 842 .

${ }^{16}$ U.S. Constitution, Article I, Section 8, Clause 15: Militia.

${ }^{17}$ Mahon, 1983, p. 110-111.

${ }^{18}$ Hill, 1964, pp. 130, 134-135.

${ }^{19}$ Charles Sydney Clark, "The Future of the National Guard," The North American Review, Vol. 170, No. 522, May 1900, p. 738.

${ }^{20}$ Clark, 1900, p. 738.

${ }^{21}$ Cosmas, 1998, p. 7.
} 
reformer Emory Upton, for example, proposed creating the "National Volunteers" for precisely this reason, although his proposal never came to fruition. ${ }^{22}$

Nonetheless, the United States fought numerous wars throughout this period: the MexicanAmerican War, the Civil War, the Spanish-American War, and smaller wars against the American Indians on frontiers. And the United States conducted smaller-scale interventions abroad. Indeed, the U.S. Marine Corps alone landed troops 180 times in 37 countries from 1800 to 1934 and was actively engaged in fighting small wars of one sort or another for almost all that time. $^{23}$ In all these cases, the United States simply used regular forces, supplemented by volunteers if needed.

Finally, as for being citizen soldiers, the proposition remained mostly true, although somewhat less so than during the militia period. Unlike the militia period, as their name implies, service in the voluntary companies was not an obligatory part of citizenship. Indeed, obligatory military service - in any form or component — proved increasingly unpopular. When the Union tried to institute obligatory service in the Union Army in 1863, the result was not an outpouring of civic virtue, but draft riots. Indeed, in the July 1863 draft, 30 percent "used commutation or substitution to evade service, and another 65 percent were declared exempt." 24 The later drafts produced only marginally higher yields - with 19 percent of those "held to service" personally serving. ${ }^{25}$

The volunteer companies, and later the National Guard, maintained the other aspects of citizen soldiers, however. Despite the demise of compulsory service, they still attracted elements from a broad swath of society. Immigrant groups - German, Irish, and Scottish — often formed their own volunteer companies. ${ }^{26}$ The Guard also recruited from a range of economic classes as well, with a mixture of factory workers, business men, clerks, and farmers showing up on the state rolls. ${ }^{27}$ As for its democratic legitimacy, the Guard became more popular - or at least more successful at navigating the democratic process. The National Guard Association was formed in 1879 , and after a rocky start, became increasingly adept at winning friends in Congress and the Executive Branch. ${ }^{28}$

Finally, the Guard retained its civilian feel, although it was slowly developing its own institutional character, especially by the latter half of the 19th century. The Guard was still

\footnotetext{
${ }^{22}$ Louis Cantor, "Elihu Root and the National Guard: Friend or Foe?" Military Affairs, Vol. 33, No. 3 , December 1969, p. 363.

${ }^{23}$ U.S. Marine Corps, Small Wars Manual, Washington, D.C.: Government Printing Office, 1940, p. 2

${ }^{24}$ Krebs, 2009, p. 157.

${ }^{25}$ Krebs, 2009, p. 157.

${ }^{26}$ Cunliffe, 1968, pp. 223-227.

${ }^{27}$ For example, see the demographic breakdown of the New Jersey National Guard. Martha Derthick, The National Guard in Politics, Cambridge, Mass.: Harvard University Press, 1965, p. 19.

${ }^{28}$ Derthick, 1965, pp. 20-22.
} 
composed mostly of part-time soldiers. By 1880, regular Army officers inspected militia summer encampments "at the request of the state authorities," but they remained relatively few in number. ${ }^{29}$ In 1894, for example, the War Department assigned 27 full-time and another 40 parttime regular army officers to serve as National Guard instructors. ${ }^{30}$ That said, with the growth of the National Guard Association and the National Guard Bureau, the Guard was developing its own bureaucratic identity - distinct from the regular army but an "integral component of the national military force.",31

By 1900, however, most recognized that the National Guard had evolved into something quite different from what the militia had been at the start of the century. ${ }^{32}$ On the one hand, "militia service in the sense in which Washington meant it, and in the sense in which it was understood in the early frontier villages, was not continued." 33 Many of these changes were positive: The Guard was slowly evolving into a more useful instrument for federal policyalthough more so for controlling state-level domestic unrest than national warfighting. At the same time, with the abolition of the compulsory service requirement, the Guard began to lose some of its citizen soldier sheen.

\footnotetext{
${ }^{29}$ Todd, 1941, p. 159.

${ }^{30}$ Edward M. Coffman, The Old Army: A Portrait of the American Army in Peacetime, 1784-1898, New York: Oxford University Press, 1986, p. 251.

${ }^{31}$ Mahon, 1983, pp. 119, 124.

${ }^{32}$ Clark, 1900, p. 730.

${ }^{33}$ Colby and Glass, 1943, p. 841.
} 


\section{The Strategic Reserve (1903-1990)}

In 1903, the Dick Act became the "cornerstone" of the modern National Guard. ${ }^{1}$ It expanded on efforts already under way in the late 19th century to turn the Guard into a strategic reserve that could fill out the regular Army, as needed. At its core was a simple quid pro quo relationship: In exchange for increased federal oversight and control (if needed), the Guard received $\$ 2$ million in federal funding in 1903, up fivefold from $\$ 400,000$ the year before. ${ }^{2}$ Later legislation - the National Defense Acts of 1916 and 1920 - made the Guard a component of the U.S. Army, gave the federal government more latitude to "prescribe the qualifications for their officers," and allowed for the Guard's federalization in exchange for more federal funding of drill and field pay. ${ }^{3}$ The legislation never took the Guard away from the states but by 1933 , 12,381 of 13,364 National Guard officers also commissioned into the Federal Reserve. ${ }^{4}$ These reforms - combined with the ANG's creation in 1947-largely gave the Guard its modern form and enabled it to make important contributions, particularly during the World Wars and the Korean War.

Thanks to these reforms, the first claim - the National Guard's centrality to American national security - became increasingly true. During World War I, as border tensions heated up in 1916, the National Guard deployed 156,414 men for nine months along the Mexican border. ${ }^{5}$ The National Guard contributed two of the first four divisions - the 26th and 42nd - to arrive in France as part of the American Expeditionary Force, and ultimately, 18 out of 43 divisions serving on the Western front came from the National Guard. ${ }^{6}$ In the estimation of the American Expeditionary Force commander, General John Pershing, the Guard "performed very excellent service" - especially given that they were underfunded and unevenly trained prior to the war. Similarly, during World War II, the National Guard contributed 18 divisions and some 300,000 troops to the overall effort, fighting in such critical engagements as the D-Day invasion. ${ }^{8}$ Roughly 34 percent of the Army National Guard — some 138,600 in total—and 80 percent of the

\footnotetext{
1 Cantor, 1969, p. 370.

2 Todd, 1941, p. 163; Colby and Glass, 1943, pp. 843-844; and Cantor, 1969, p. 370.

3 Colby and Glass, 1943, pp. 844, 847.

${ }^{4}$ Colby and Glass, 1943, pp. 846, 850.

5 Todd, 1941, p. 166.

6 James W. Rainey, “The Questionable Training of the AEF in World War I," Parameters, 1992, p. 95; and Myers, 2004, p. 5.

7 Todd, 1941, p. 168

${ }^{8}$ Michael D. Doubler, I Am the Guard: A History of the Army National Guard, 1636-2000, Department of the Army, 2001, p. 186.
} 
newborn ANG — some 45,000 airmen in total-mobilized for Korea. ${ }^{9}$ Many Guardsmen went on to serve with distinction and the new ANG eventually produced four jet aces. ${ }^{10}$

As impressive as these contributions were, however, the National Guard still never provided the plurality of American combat power (contrary to the first hypothesis). The World War I Army largely came from the "National Army"-a new component composed of draftees and totaling nearly 3 million on November 11, 1918. ${ }^{11}$ The World War II statistics paint an even starker contrast: The active-duty Army alone_-never mind the other services_-peaked at 6 million men in uniform in 1945, dwarfing the National Guard's contribution. ${ }^{12}$ Similarly, the size of the active-duty Army during the Korean War in 1952 peaked at 1.6 million. ${ }^{13}$ Moreover, American mobilization policy at the time rotated soldiers out of Korea after a set period, so the number of Guardsmen in Korea declined dramatically toward the end of the war. In fact, by June 30,1953 , less than a month before the Armistice was signed, only 1.5 percent of all Army soldiers on active duty were volunteer Guardsmen and Reservists. ${ }^{14}$ And so, while the Guard fought in all three conflicts, draftees did most of the fighting.

Moreover, as in previous eras, National Guard units often were subordinated to regular Army officers. When selecting his advanced party to go to France in 1917, Pershing chose 157 officers, including 50 reserve officers but no Guardsmen. ${ }^{15}$ Similarly, during World War II, Army Ground Forces commander General Lesley McNair and China, Burma, and India commander General Joseph Stillwell did not hide their disdain for the Guard's generals, who they felt owed their ranks to political ties rather than military competence. ${ }^{16}$ And during the Korean War, most Air Guardsmen ended up augmenting the active force rather than fighting with their reserve units. ${ }^{17}$

After Korea, the Guard - and the Reserves at large — focused more on domestic crises. As depicted in Figure 1, some 65,000 Air and Army Guardsmen mobilized for the Berlin Crisisincluding two "high priority" Army National Guard Divisions (the 32nd and the 49th) — while

\footnotetext{
${ }^{9}$ Hill, 1964, p. 507; Charles J. Gross, "The Air National Guard: Past, Present, and Future Prospects,” Airpower Journal, Winter 1996, p. 62; and Eliot A. Cohen, "Constraints on America's Conduct of Small Wars," International Security, Vol. 9, No. 2, Fall 1984, p. 157.

${ }^{10}$ Gross, 1996, p. 62.

${ }^{11}$ Rainey, 1992, p. 89; and Doubler, 2001, p. 161.

12 Thom Shanker and Helene Cooper, "Pentagon Plans to Shrink Army to Pre-World War II Level," New York Times, February 23, 2014. A snapshot from July 1940 through June 1941 further depicts the breakdown between components. Of the 1,248,393 enlisted, called to duty, or inducted into the service during the period, 325,629 came from the regular Army, 293,491 were Guardsmen, and the vast majority-629,273 - were selectees. Marvin A. Kreidberg and Merton G. Henry, History Of Military Mobilization in the United States Army 1775-1945, Washington, D.C.: Department of the Army, 1955, p. 590.

${ }^{13}$ Shanker and Cooper, 2014.

${ }^{14}$ Hill, 1964, p. 514.

${ }^{15}$ Heller, 1991, p. 6.

${ }^{16}$ Heller, 1991, p. 8.

${ }^{17}$ Gross, 1996, p. 62.
} 
only approximately 19,600 Guardsmen served in the Vietnam War. ${ }^{18}$ The Guard, however, played a more active role in homeland defense. As the Cold War heated up and the Soviet nuclear threat increased, the ANG manned fighter wings and the Army National Guard fielded air defense artillery battalions. ${ }^{19}$ The Guard also routinely confronted domestic instability. Of the ten times the National Guard has been federalized for domestic law enforcement since the Second World War, seven occurred between 1957 and 1970, mostly responding to unrest caused by the Vietnam War and racial tensions. ${ }^{20}$

Figure 1. National Guard Participation in Overseas Conflicts (Strategic Reserve Period)

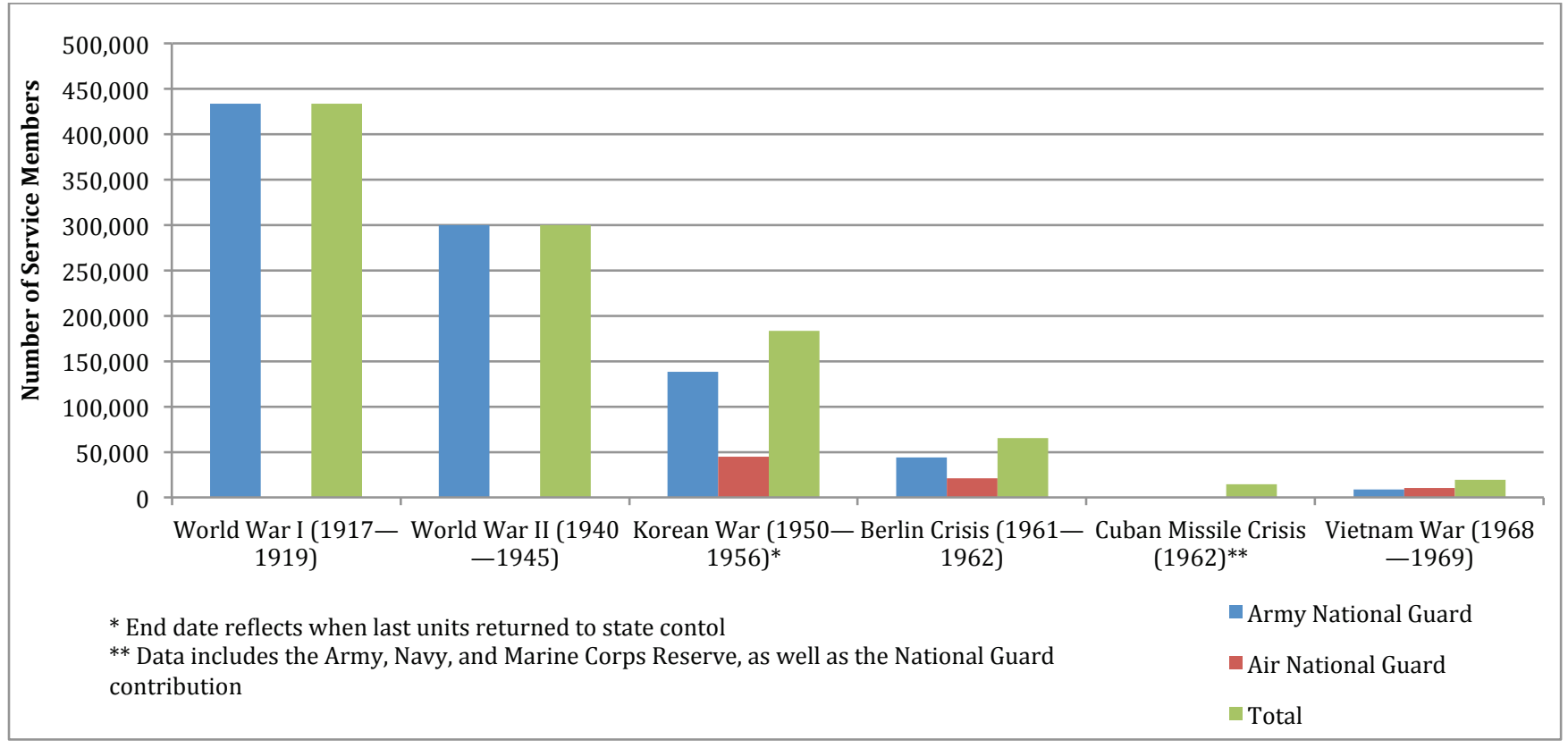

SOURCES: Doubler, 2001, pp. 161, 186, 206, 218, 226; Susan Rosenfeld and Charles J. Gross, Air National Guard at 60: A History, Washington D.C., Air National Guard, 2007, pp. 7, 12, 13; and Lawrence Kapp and Barbara Salazar Torreon, Reserve Component Personnel Issues: Questions and Answers, Washington, D.C.: Congressional Research Service, RL30802, June 13, 2014, p. 9.

The Guard's increasingly active role in national policy during the 20th century came at a cost to its second claim - that it prevents the United States from fighting controversial foreign wars. Beginning with the Dick Act, the Guard increasingly relied on the federal government for its budget. In 1891, the states paid for roughly 85 percent of their National Guard. ${ }^{21}$ By 1933, states paid approximately a third of the Guard's costs; three decades later, in 1963, they contributed

\footnotetext{
18 See, also, Brayton, 1972, p. 141.

${ }^{19}$ Brayton, 1972, p. 142.

${ }^{20}$ Carol Guensburg, "National Guard Deployments for Civil Unrest Uncommon in U.S.," Voice of America, August 18, 2014.

${ }^{21}$ Mahon, 1983, p. 124. In 1891, the states paid for $\$ 2,339,086$, compared with the federal government's $\$ 387,000$.
} 
only 6 percent. $^{22}$ And as federal government picked up more of the tab, it demanded that, in return, the Guard become more responsive to its needs.

In fact, throughout the 20th century, the federal government successfully fought a series of legal battles to expand its hold over the Guard. As late as 1912, Taft administration Attorney General George Woodward Wickersham concluded that the President could not deploy the Guard abroad "as a part of an army of occupation." 23 Later attorneys general, however, fought to expand the federal government's ability to deploy the Guard wherever and whenever it was needed. Even in the mid-1980s, governors still challenged federal authority to deploy the National Guard overseas. ${ }^{24}$ These state challenges to federal authority mostly fell flat, however, reinforcing one of the key trends in the Guard's evolution during this period-increasing federal control over the institution. ${ }^{25}$

Deploying Guardsmen overseas still carried significant political costs. Lyndon Johnson, for example, chose not to deploy the Guard in substantial numbers to Vietnam partially because of the fear of domestic political backlash. ${ }^{26}$ As former Nixon administration Secretary of Defense Melvin Laird notes, "As unpopular as the draft was, it was still an easier sell for Johnson than deploying whole National Guard and Reserve units out of the communities in middle America."27

The argument about political hesitation to deploy Guardsmen requires at least two caveats, however. First, the reluctance to deploy the Guard was not a hard and fast rule. As mentioned before, the Guard participated in both World Wars and, perhaps more important, in Korea-even though it was a "police action" on paper. Conversely, Johnson's decision against using the Guard in Vietnam was only partially driven by domestic political costs. He also wanted to avoid provoking a larger Southeast Asia war and direct Chinese or Soviet intervention. ${ }^{28}$ Second, and more important, the political hesitation and legal hurdles to deploying the Guard did not actually prevent wars from being fought. The Johnson administration still fought the Vietnam War-it just did so mostly without the Guard. Even after Vietnam, when the Total Force Policy ensured

\footnotetext{
22 Mahon, 1983, p. 246.

23 John G. Kester, "State Governors and the Federal National Guard," Harvard Journal of Law and Public Policy, Vol. 11, No. 1, 1988, p. 186.

${ }^{24}$ In 1986, for example, Maine Governor Joseph E. Brennan protested the deployment of Maine Guardsmen to a training exercise in Honduras. Eventually, 13 other governors either followed suit or expressed reservations about such deployments. Kester, 1988, pp. 177-179.

${ }^{25}$ Kester, 1988, pp. 177-179.

${ }^{26}$ Gross, 1996, p. 64; John D. Stuckey and Joseph H. Pistorius, "Mobilization for the Vietnam War: A Political and Military Catastrophe," Parameters, Vol. 15, No. 1, 1985, pp. 26-38; Herbert Y. Schandler, The Unmaking of a President: Lyndon Johnson and the Vietnam War, Princeton, N.J.: Princeton University Press, 1977, p. 39; and Stanley Karnow, Vietnam: A History, New York: Viking Press, 1983, p. 498.

27 Melvin R. Laird, "Iraq: Learning the Lessons of Vietnam," Foreign Affairs, Vol. 84, No. 6, November-December 2005, p. 40.

${ }^{28}$ Mahon, 1983, p. 242; and Doubler, 2001, p. 223.
} 
that the military would need to mobilize reservists for the next major conflict, the United States still regularly went to war - as shall be detailed in the next chapter. ${ }^{29}$

The National Guard's role as a check on federal power also diminished in another dimension. In a watershed event regarding federal versus state control of the Guard, Arkansas Governor Orville Faubus attempted in 1957 to use the Guard to block the federal court-ordered integration of Little Rock's high schools. In response, President Dwight Eisenhower federalized the Arkansas National Guard and deployed elements of the 101st Airborne Division to uphold the court's decision. A few years later, in 1963, when Governor George Wallace attempted to use the Alabama National Guard to prevent the integration of the University of Alabama, President John F. Kennedy also federalized the Guard to enforce the policy. These incidents were not only significant milestones for race relations in the United States, but for the National Guard as well, demonstrating the federal governments' increasing control over the Guard. ${ }^{30}$

As for the third proposition, the Guard's claim on the title of citizen soldier also arguably suffered during this period. Despite the draft, military service was never fully obligatory. As Barry Strauss notes, "Even with the draft in effect, only about 41 percent of American men of the Vietnam generation served in the military." 31 As a result, the compulsory element of the citizen soldier was lacking.

More problematically and contrary to the "universal" element of the citizen soldier ideal, the Guard became one way for the wealthy and the well-connected to avoid the Vietnam War. Most notably, perhaps, George W. Bush flew for a Texas ANG squadron nicknamed a "champagne unit" because it was composed largely of Texas' political and economic elite. ${ }^{32}$ Bush was not alone: A New York Times investigation in 1988 leveled similar accusations against more than a dozen congressmen and senators - both Republicans and Democrats, from all corners of the country. ${ }^{33}$ Other elites found their way into the Guard as well: At one point, ten Dallas Cowboys' players all belonged to the same Guard unit. ${ }^{34}$ While these were exceptions rather than the rule, these anecdotes question the extent to which the Guard actually reflected American society.

The flip side of this trend, of course, was that the Guard still reflected the "civilian" quality of the citizen soldier. Polls from the Vietnam period showed about three-quarters of Guardsmen enlisted because of the draft. Only about 3 percent of Guardsmen reenlisted after their first tour and only 0.5 percent of active-component veterans chose to continue on in the Guard. As Mahon

\footnotetext{
${ }^{29}$ Heller, 1991, p. 26.

30 John F. Romano, "State Militias and the United States: Changed Responsibilities for a New Era," The Air Force Law Review, Vol. 56, 2005, p. 246.

${ }^{31}$ Strauss, 2003, p. 71.

${ }^{32}$ Michael Dobbs, "Democrat Says He Helped Bush into Guard to Score Points," Washington Post, September 4, 2004.

${ }^{33}$ William E. Schmidt, “Some Now in Congress Joined Reserve or Guard," New York Times, 1988.

${ }^{34}$ Mahon, 1983, p. 243.
} 
notes, "It was obvious that few young men in the early years of the decade [the 1970s] had the slightest interest in a military career.",35

On a more positive note, despite these trends and the social turbulence of the second half of the 20th century, the Guard's "legitimacy" - as Mahon also notes_ “survived with relatively minor scars." 36 While Gallup polls show that Americans' confidence in the military sank to an all-time low with Vietnam, these polls did not directly ask about the National Guard. ${ }^{37}$ Perhaps more relevant to the Guard's legitimacy was its role at home. As David Adams notes, the Guard conducted more than 560 internal military interventions between the fiscal years (FYs) 1961 and 1983 , often called by the state but sometimes at federal behest, involving more than a halfmillion troops. ${ }^{38}$ While these missions were not new, the scale "surpasses anything before in U.S. history." $" 39$ Many of these interventions proved controversial; some-most notably, when National Guard troops fired on student protesters at Kent State-remain so today. ${ }^{40}$ Even when these domestic responses turned ugly, however, the public still often sided with the Guard. Despite the vocal outrage after the Kent State shooting and the years of investigation that followed, a Gallup poll found that 58 percent of Americans blamed the students and only 11 percent blamed the Guardsmen for the incident. ${ }^{41}$

\footnotetext{
${ }^{35}$ Mahon, 1983, p. 249.

${ }^{36}$ Mahon, 1983, p. 247.

${ }^{37}$ Gallup, Military and National Defense, undated.

38 David Adams, "Internal Military Intervention in the United States," Journal of Peace Research, Vol. 32, No. 2, 1995, p. 204.

39 Adams, 1995, p. 205.

40 Noah Adams, "Shots Still Reverberate for Survivors of Kent State," National Public Radio, May 3, 2010.

41 Stewart J. Lawrence, “The Unquiet Ghosts of Kent State," The Guardian, May 4, 2011.
} 


\section{The Move to an Operational Reserve (1991-Present)}

The origins of the "Operational Reserve," arguably, lie two decades earlier in the Total Force Policy of the 1970s. Faced with budget cuts and manpower problems in the aftermath of the Vietnam War, Secretaries of Defense Melvin Laird and James R. Schlesinger proposed pairing reserve units - including the National Guard — with active-component units. ${ }^{1}$ Army Chief of Staff General Creighton Abrams took the policy even further-permanently assigning National Guard brigades to active-component divisions and ensuring, at least in theory, that the Army would need to mobilize the Guard to fight any major conflict. ${ }^{2}$ In practice, integrating the forces did not come easily. Famously, during Operation Desert Storm, the Defense Department called up three National Guard brigades to "round out" active-component divisions in 1990; only onethe 48th Infantry Brigade - was ever certified as combat-ready and only after it was too late to deploy during the Gulf War. ${ }^{3}$ Of the 62,411 Army Guardsmen mobilized for that conflict, only 37,484 served in combat. ${ }^{4}$ The ANG mobilized 12,456 Guardsmen during the war and eventually flew a range of missions - including airlift, refueling, and attack and reconnaissance sorties. ${ }^{5}$ It was only after the Gulf War, as the active component shrank and the number of small-scale interventions grew, that the National Guard — and the reserve component as a whole - became increasingly operational, deploying regularly throughout the 1990s and becoming dramatically more active during the Global War on Terrorism (see Figure 2). And as deployments picked up, the first claim - the centrality of the Guard to American national security - became increasingly true.

\footnotetext{
${ }^{1}$ Doubler, 2001, pp. 240-241.

${ }^{2}$ Doubler, 2001, pp. 242-243.

${ }^{3}$ The reasons why the National Guard brigades did not deploy to Desert Storm is a matter of fierce historical debate - with some of explanations focusing on funding, training, leadership, and individual soldier readiness issues. See Government Accountability Office, National Guard: Peacetime Training Did Not Adequately Prepare Combat Brigades for Gulf War, Washington, D.C., GAO/NSIAD-91-263, September 24, 1991; Government Accountability Office, Army Training: Replacement Brigades Were More Proficient Than Guard Roundout Brigades, Washington, D.C., GAO/NSIAD-93-4, November 1992; Les' Melnyk, Mobilizing for the Storm: The Army National Guard in Operation Desert Shield and Desert Storm, National Guard Bureau Office of Public Affairs Historical Services Division, 2001, pp. 18-21; and Center for Military History, War in the Persian Gulf: Operations Desert Shield and Desert Storm August 1990-March 1991, Washington, D.C.: Center for Military History, 2010, p. 23-27.

${ }^{4}$ Doubler, 2001, p. 283.

${ }^{5}$ Rosenfeld and Gross, 2007, p. 16.
} 
Figure 2. National Guard Participation in Overseas Conflicts (Operational Reserve Period)

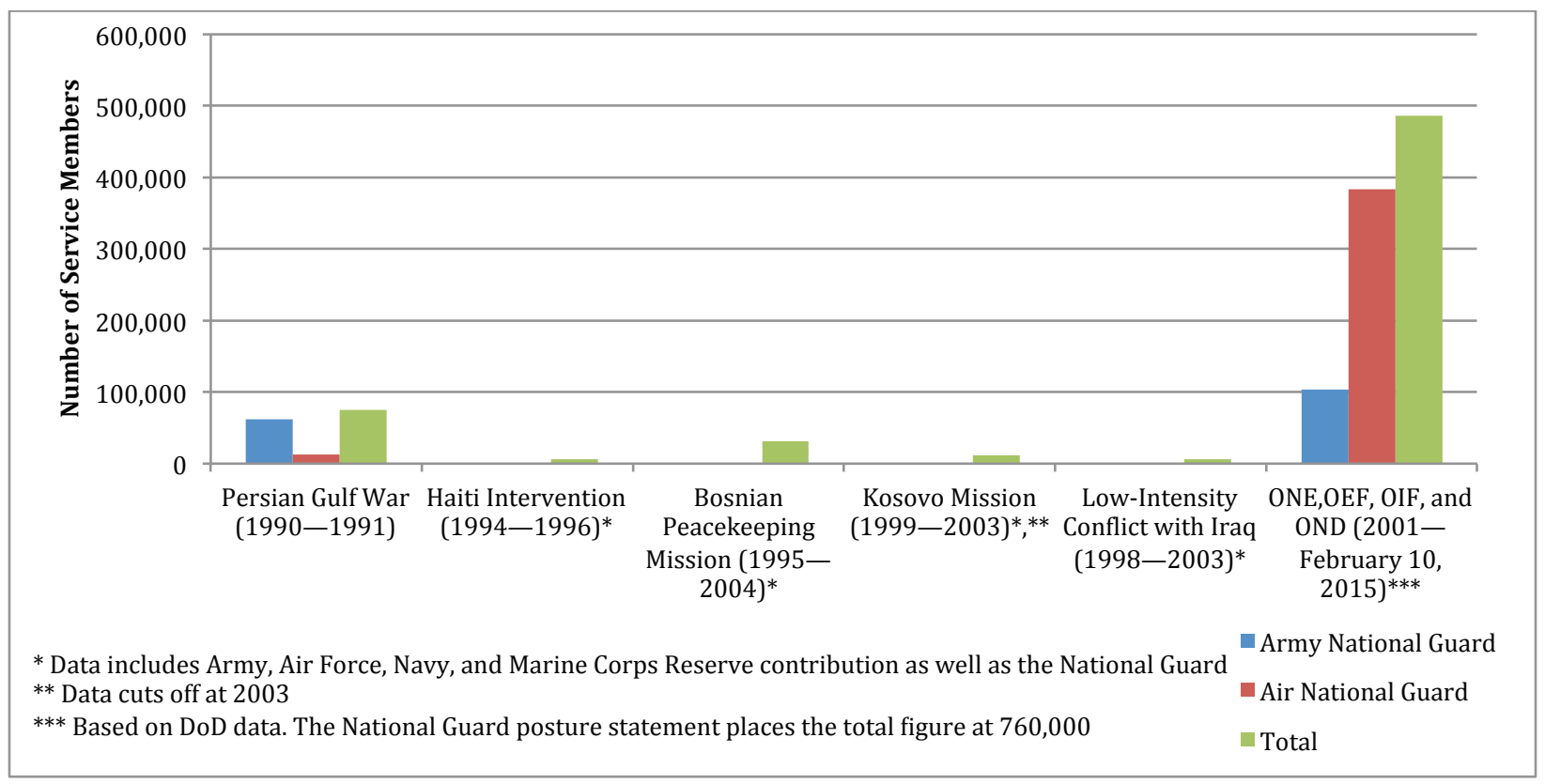

SOURCES: Doubler, 2001, p. 283; Rosenfeld and Gross, 2007, p. 16; Kapp and Torreon, 2014, p. 10; and National Guard Bureau, 2015, p. 23; U.S. Department of Defense, "Reserve Components, Unique SSAN Activations," February 10, 2015.

NOTE: ONE=Operation Noble Eagle, OEF=Operation Enduring Freedom, OIF=Operation Iraqi Freedom, and OND=Operation New Dawn.

After the Gulf War, the peacekeeping missions of the 1990s provided new opportunities for the Guard to gain operational experience. As the Gulf War demonstrated, the Army National Guard's Achilles heel was readiness. ${ }^{6}$ Predictable peacekeeping rotations, however, offered the Army National Guard sufficient time to mobilize. After the Iraq War kicked off and the demand for troops skyrocketed, the National Guard assumed responsibility for the Kosovo peacekeeping mission from 2003 to 2013 . $^{7}$

For its part, the ANG underwent a transformation after the Gulf War. Thanks to declining budgets and the Base Realignment and Closure Commission's decision to consolidate military facilities throughout the United States, Secretary of Defense Les Aspin transferred the 1st Air Force, responsible for the air defense of the United States, to the ANG. ${ }^{8}$ Simultaneously, the ANG expanded its airlift and tanker fleets, and by 1996, it provided 43.9 percent of Air Force's tactical airlift and 43.2 percent of the KC-135 air refueling capabilities. ${ }^{9}$

\footnotetext{
${ }^{6}$ See Klimas, Darilek, Baxter, et al., 2014, p. 2.

7 Steven Beardsley, “Active-Duty Troops to Deploy to Kosovo for First Time in a Decade," Stars and Stripes, March 13, 2013.

${ }^{8}$ Air National Guard, ANG Heritage: Missions, Wars and Operations, undated.

${ }^{9}$ Gross 1996, p. 60.
} 
As with the rest of the American military, the terrorist attacks of September 11, 2001, and the Iraq War had a profound effect on the Guard. In the immediate aftermath of 9/11, more than 7,000 Guardsmen deployed to 429 airports while Air Guardsmen stepped up patrolling the skies. Between that time and February 2003, 170,000 Guardsmen and reservists had been activated for homeland security duties. ${ }^{10}$ Especially, after the Iraq War started, the Guard also took on an increasingly active role abroad - deploying to both the Iraq and Afghanistan Wars. As one of the Army National Guard's promotional slides notes, "at one point in 2005, Army National Guard brigades made up more than $50 \%$ of U.S. Army combat brigades in Iraq, the Army Guard's largest combat role since WWII." 11 Indeed, of the 152,000 troops in Iraq in October 2005, about one-third - 49,000 — came from the Army National Guard, with the Army Reserve providing another 22,000 and the Marine Corps Reserve providing another 4,000, respectively. ${ }^{12}$

Combat experience and additional resources improved the quality of the force. For example, the 2015 National Guard Bureau Posture Statement says that "numerous commanders have stated they cannot tell the difference in performance between active duty and National Guard Soldiers and Airmen on the battlefield," and "the National Guard has proven itself as indistinguishable from active forces in battle at around one-third the cost to sustain during peacetime." 13 Hargett, the President of the National Guard Association, proclaimed, "After a decade of war, the Guard meets, and many times exceeds, the readiness and training standards for deployment as its active counterparts." 14 And in a recent article in the Army War College's Parameters, then-Maine Adjutant Brigadier General James Campbell asked, "How many National Guard units must fight and succeed, suffer casualties, earn decorations and citations, and serve with dedication and honor before we stop this destructive debate and make no distinction between organizations, regardless of component?" 15

Two important caveats are in order about the Guard's role in Afghanistan and Iraq, however. First, despite the increased Guard participation, the vast majority of soldiers deploying to Iraq and Afghanistan still came from the active component (Figure 3). Second, even when deployed, the Guard and the active component often performed different roles. Of the 47 Army National Guard Brigades deployed to Iraq and Afghanistan between 2001 and 2013, only 17 were assigned counterinsurgency missions (the rest were tasked with either training local security forces or other security missions). Moreover, the majority of these brigades (9 out of 17) took on the counterinsurgency mission between 2004 and 2006, and none had this mission between the

\footnotetext{
${ }^{10}$ Richard Kohn, "Using the Military at Home: Yesterday, Today, and Tomorrow," Chicago Journal of International Law, Vol. 4, No. 1, 2003, pp. 172-173.

${ }^{11}$ U.S. Army National Guard, 2008.

12 "Death Toll Rises for U.S. Reservists in Iraq," USA Today, October 10, 2005.

${ }^{13}$ National Guard Bureau, 2015, pp. 20, 61.

${ }^{14}$ Hargett, 2013, p. 4.

${ }^{15}$ Campbell, 2014, p. 104.
} 
seminal years of the Iraq Surge between 2007 and 2008. In fairness, as former National Guard Bureau director Lieutenant General Steven Blum noted, "units do not get to select their mission assignments." 16

Figure 3. Service Members Deployed to Iraq and Afghanistan, 2001-2008

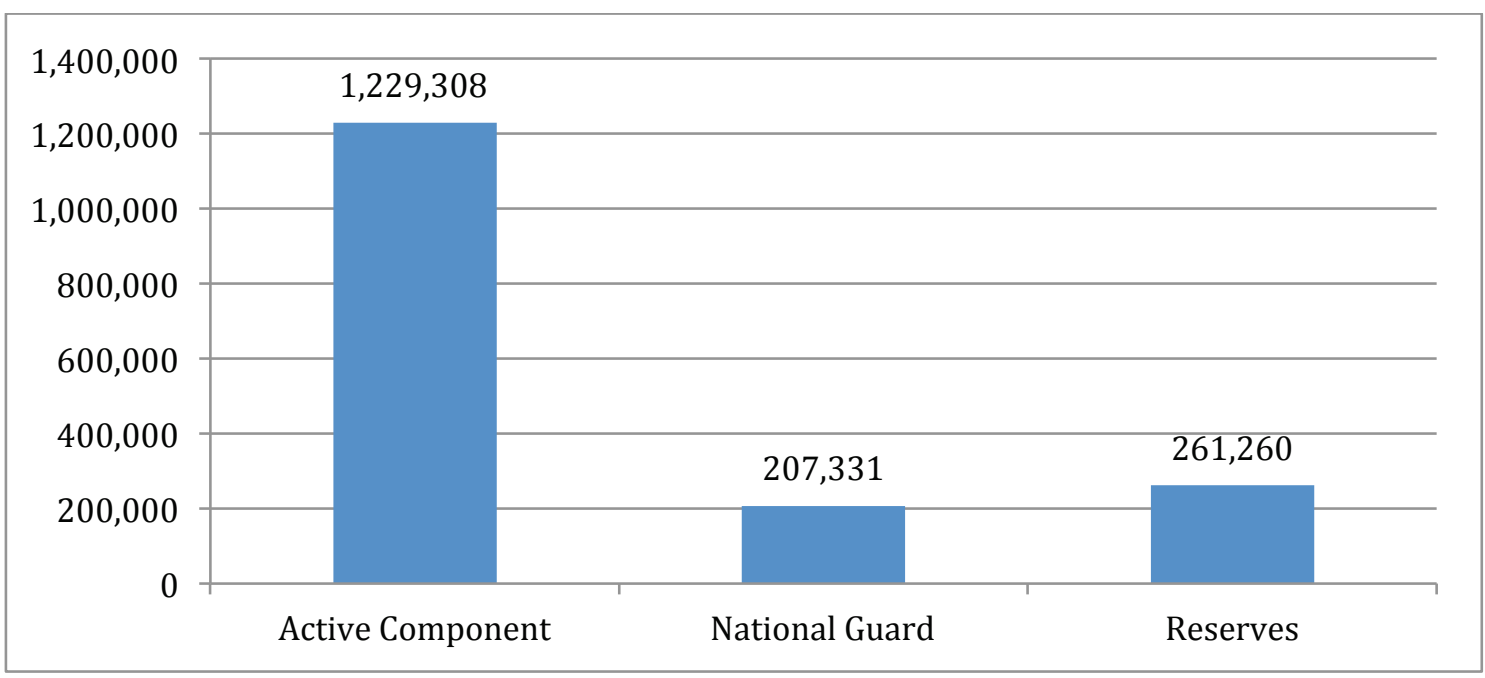

SOURCE: Michael Waterhouse and JoAnne O’Bryant, "National Guard Personnel and Deployments: Fact Sheet," Washington, D.C.: Congressional Research Service, May 1, 2008.

Historically speaking, the ANG also has performed different missions than the active component. The ANG provides 70 percent of the Air Force's communications and air traffic control capability and its fleet comprises 40 percent of the Air Force's refueling capacity and 38 percent of its airlift capacity, but only 31 percent of its fighter capacity and 17 percent of its intelligence, surveillance, and reconnaissance capability. ${ }^{17}$ As a result of their different capabilities, the active-component Air Force provided different types of support in the Iraq and Afghanistan Wars. For example, between FY 2006 and FY 2010, the U.S. Air Force provided almost all MQ-1 Predator support-more than 570,000 hours_-although ANG has been expanding in this area. ${ }^{18}$ Even when the two components did have the same airframes, the Guard

${ }^{16}$ Sydney Freedberg, Jr., “Budgets \& 'Betrayal': National Guard Fights to Keep Apache Gunships,” Breaking Defense, January 23, 2014a.

${ }^{17}$ National Guard Bureau, 2015, pp. 17, 20. For the intelligence, surveillance, and reconnaissance statistics, see Amaani Lyle, “Air Force Secretary Reports on Total Force Balance,” American Forces Press Service, April 30, 2014.

18 The active-component Air Force logged some 615,594 hours, 93.8 percent of which was operational. The ANG, by contrast, logged 1,531 hours, all in training. Albert A. Robbert, James H. Bigelow, John E. Boon, Jr., Lisa M. Harrington, Michael McGee, S. Craig Moore, Daniel M. Norton, and William W. Taylor, Suitability of Missions for the Air Force Reserve Components, Santa Monica, Calif.: RAND Corporation, RR-429-AF, 2014, p. 24. More recently, the ANG has expanded its capabilities in this area; in FY 2015 it owned about 18 percent of the MQ-1 Predator and MQ-9 Reaper fleet. National Guard Association of the United States, "FY15 Fact Sheet: Ground Based and Airborne Sense and Avoid Capability for ANG Remotely Piloted Aircraft," undated-a. 
often took on different roles - providing the vast majority of air defense missions flown in the United States, for example. ${ }^{19}$

The move to an operational reserve also further undercut the Guard's claim that they prevent the United States from fighting controversial foreign wars. Indeed, the Guards' leaders today cast it as a force that wants to deploy. A former director of the Army National Guard, Lieutenant General William Ingram, commented, "Our soldiers expect to be gainfully employed. Every one of them has either enlisted or reenlisted since $9 / 11$, motivated by a desire to serve their country. One weekend a month and two weeks in the summer are not what they signed up for." 20 And as the 2015 Posture Statement notes, of the 44,000 requests for manpower in FY 2013, the ANG filled almost 90 percent with volunteers. ${ }^{21}$ If the Guard is indeed raring to go, then it may not act as a brake on executive power as its proponents contend. ${ }^{22}$

More profoundly, perhaps, as the Guard became more operational, the veracity of the third claim - as the modern embodiment of the citizen soldier - declined proportionally. Ever since the move to an all-volunteer force, the obligatory aspect has disappeared. More interestingly, in contrast to Janowitz's argument of democratic legitimacy and contrary to the Guard's claims, even as Americans have grown increasingly personally disconnected from the military, they have remained strongly supportive of it as an institution. A recent 2013 Pew poll found that 78 percent of Americans thought the military contributed "a lot" to society's well-being, down from 84 percent in 2009 but still higher than any other profession. ${ }^{23}$ Gallup found a similar trend: The percentage of Americans expressing "a great deal" or "quite a lot of confidence" in the military consistently ticked upward from 58 percent in 1975 to 74 percent in 2014, in a series of annual or semiannual polls. ${ }^{24}$ Unfortunately, neither Pew nor Gallup captured the differences between the Guard and the active component per se, but evidence seems to contradict the idea that familiarity breeds legitimacy. If anything, the more removed most Americans are from the military, the more they support and respect it.

\footnotetext{
${ }^{19}$ Then-Principal Deputy Assistant Secretary of Defense (Homeland Defense) Peter Verga estimated the percentage at more than 90 percent. Peter Verga, "Transformation of the Reserve Component," in Threats at Our Threshold, Washington, D.C.: Center for Strategic and International Studies, 2006, p. 147.

${ }^{20}$ William E. Ingram, Jr., “The Army National Guard: Where We've Been and Where We Want to Go," Army, August 2012, p. 28.

${ }^{21}$ U.S. National Guard Bureau, 2015, p. 23.

22 Even as early the mid-1990s, there was some evidence of the convergence of attitudes (in this case, toward peacekeeping missions) between reserve- and active-component soldiers. David R. Segal and Ronald B. Tiggle, "Attitudes of Citizen-Soldiers Toward Military Missions in the Post-Cold War World," Armed Forces and Society, Vol. 23, No. 3, 1997, pp. 373-390.

${ }^{23}$ Pew Foundation, "Public Esteem for Military Still High,” July 11, 2013.

${ }^{24}$ Gallup, 2014. Importantly, older studies found that confidence in the military may be concentrated in select demographics - male (as opposed to female), conservative (rather than liberal), white (as opposed to minorities), and Depression, Generation X, and Millennial generations (but not the Baby Boom). See David C. King and Zachary Karabell, The Generation of Trust: Public Confidence in the U.S. Military since Vietnam, Washington, D.C.: AEI Press, 2003, pp. 11-12, 17.
} 
The Guard today still remains more universal than the active component. According to the 2012 Demographics: Profile of the Military Community, more than 70 percent of the active component reside in just ten states and more than 42 percent reside in four states - California, Texas, Virginia, and North Carolina. ${ }^{25}$ Thanks to post-Cold War base consolidation, the active force tends to be concentrated into a select few superbases within these states - such as Fort Hood, Naval Base San Diego, or Joint Base San Antonio. By contrast, during the same year (2012), only 42 percent of the selected reserves lives in the top ten states and one would have to include 22 states to find 70 percent of the force. ${ }^{26}$ Moreover, since reservists often want to drill close to home, the reserve component tends to be spread out even within these states. More important, since Guard units report to state adjutant generals, Guardsmen identify with their home states and state governors are more likely to fight to keep bases in their state open.

That said, the days when the Guard - like the military at large - truly reflected the United States are long gone. As of September 2013, there were only 465,000 Guardsmen in the United States, well less than 0.2 percent of the American population. ${ }^{27}$ Given the expected end-strength reductions and the predicted growth of the overall American population, this percentage will likely decline in the future. Already, a 2011 Pew Foundation study found that fewer Americans - particularly among younger generations - had an immediate relative who served in the military. ${ }^{28} \mathrm{Pew}$ also found that those with ties to military service tend to be concentrated within select demographics, rather than reflective of the overall population. ${ }^{29}$

Finally, the transition to operational reserve, arguably, came at greatest cost to the "civilian" dimension of the citizen soldier. The Global War on Terrorism and increased military budget allowed for reservists to functionally sever their ties to the civilian sector and jump from one mobilization to another. Even before 9/11, however, the number of "full-time part-timers"those reservists whose full-time job is to support the reserve component- - has been on the rise. As depicted in Table 2, the share of "full-time support" (FTS) relative to the overall force increased by roughly 5 percent or more since the end of the Cold War. ${ }^{30}$ Increasingly, these FTS personnel are not active-component members who are temporarily detailed to support the reserve component; they are full-time Active Guard Reserve personnel or "military technicians" (typically selected reserve service members who then also work for the reserve component in their civilian capacities). While there are plenty of good reasons for the growth of FTS,

\footnotetext{
${ }^{25}$ Office of the Deputy Assistant Secretary of Defense for Military Community and Family Policy, 2012 Demographics: Profile of the Military Community, undated, p. 34.

${ }^{26}$ Office of the Deputy Assistant Secretary of Defense for Military Community and Family Policy, undated, p. 85.

${ }^{27}$ Kapp and Torreon, 2014, p. 5.

${ }^{28}$ Pew Foundation, “The Military-Civilian Gap: Fewer Family Connections,” November 23, 2011.

${ }^{29}$ Pew Foundation, 2011. Specifically, they found that white, rural-dwelling Republicans were more likely to have a relative in military service.

${ }^{30}$ Comparative numbers based on Brauner and Gotz, 1991, p. 5; and Kapp and Torreon, 2014, pp. $5,8$.
} 
especially as the warfare grows more complex and demands more sophisticated skills, this also means that there are fewer true civilians than ever before.

Table 2. Full-Time Support for the National Guard

\begin{tabular}{|c|c|c|c|c|c|}
\hline \multicolumn{3}{|c|}{ Full-Time Support for Air National Guard } & \multicolumn{3}{|c|}{ Full-Time Support for Army National Guard } \\
\hline & 1991 & 2013 & & 1991 & 2013 \\
\hline Active Guard Reserve & 8,468 & 14,557 & Active Guard Reserve & 26,199 & 31,111 \\
\hline Military technicians & 23,963 & 22,568 & Military technicians & 28,457 & 27,393 \\
\hline Active component & 640 & 208 & Active component & 546 & 184 \\
\hline Civilian & 1,944 & 208 & Civilian & 395 & 785 \\
\hline Total full-time support & 34,988 & 37,541 & Total full-time support & 55,597 & 59,473 \\
\hline Selected reserve personnel & 116,300 & 105,708 & Selected reserve personnel & 447,300 & 357,735 \\
\hline Percentage of FTS/select reserve & $30 \%$ & $36 \%$ & Percentage of FTS/select reserve & $12 \%$ & $17 \%$ \\
\hline
\end{tabular}

SOURCES: Marygail K. Brauner and Glenn A. Gotz, Manning Full-Time Positions in Support of the Selected

Reserve, Santa Monica, Calif.: RAND Corporation, R-4034-RA, 1991, p. 5; and Kapp and Torreon, 2014 , pp. 5, 8.

More significantly, multiple surveys suggest that National Guardsmen's identities and preferences might more closely resemble those of active-component soldiers, rather than of civilians. Already in the 1990s, David Segal and Ronald Tiggle found that "while the attitude of these citizen soldiers (National Guardsmen who participated in the peacekeeping missions) differed from those of active duty soldiers who have served in the Sinai MFO [Multinational Force Observers], what is most notable is how minimal these differences are."31 Similarly, in another study, psychologist and Army National Guard Colonel James Griffith argues that the Guard today often identifies as "soldier warriors" and "conservative ideologues." 32 And anthropologist Bonnie Vest found that after deployments, Guard members' identities shifted. "Soldier, as a sense of who one is, is no longer a secondarily assumed or temporarily dominant role, but a central piece in the overall sense of one's identity." 33

While the gap between reserve and active components may be narrowing, the gap between the military and broader society seems to be widening. In one of the most comprehensive studies to date, the Triangle Institute for Strategic Studies conducted a survey of military leaders between 1998 and 1999, compared it to the general society and found two key observations. First, like the other aforementioned studies, "active reservists" - the study did not separate out National Guard from Reserves_ - often mirrored their active-component counterparts in terms of

\footnotetext{
31 Segal and Tiggle, 1997, p. 388.

32 James Griffith, "Being a Reserve Soldier: A Matter of Social Identity," Armed Forces and Society, Vol. 36, No. 1, October 2009, pp. 38-64. See, also, James Griffith, "Reserve Identities: What Are They? And Do They Matter? An Empirical Examination,” Armed Forces and Society, Vol. 37, No. 4, October 2011, pp. 619-635.

33 Bonnie M. Vest, "Citizen, Soldier, or Citizen-Soldier? Negotiating Identity in the US National Guard," Armed Forces and Society, Vol. 39, No. 4, October 2013, p. 617.
} 
religious preference, home of origin, political preference, and ideological bent. ${ }^{34}$ At the same time, both groups differed sharply from the overall civilian population. For example, both active and reserve component service members identified with the Republican Party by a margin of six to one. ${ }^{35}$ Importantly, this study was conducted before the Global War on Terrorism. And while there has yet to be a similarly comprehensive analysis post-Iraq and Afghanistan, if anything, the polarizing effects of these wars and the repeated mobilization of National Guardsmen to fight these wars has likely only further blurred lines between active component and Guard profiles and sharpened the divide between them and the overall population.

Ultimately, the move to the Operational Reserve came with a tradeoff. On the one hand, while the Guard still is not the principal instrument of American combat power, it contributes more to American national security today than perhaps at any other point in its history. The Guard's increased proficiency, however, came at the expense of its other two claims: The modern Guard serves as less of a check on the United States' ability to fight foreign wars and is composed of fewer citizen soldiers than ever before.

\footnotetext{
34 Ole R. Hostli, "Of Chasms and Convergences: Attitudes and Beliefs of Civilians and Military Elites at the Start of a New Millennium," in Peter D. Feaver and Richard H. Kohn, eds., Soldiers and Civilians: The Civil-Military Gap and American National Security, Cambridge, Mass.: MIT Press, 2001, pp. 24, 26, $28,33$.

${ }^{35}$ Hostli, 2001, p. 92.
} 


\section{Demystifying the Citizen Soldier}

At first blush, two of the three claims about the National Guard partially fit the historical record (see Table 3). Only the claim that the Guard prevents the United States from fighting controversial foreign wars does not stand up to scrutiny. While mobilizing the Guard historically proved cumbersome (and, at times, politically unpopular), this has not prevented the United States from fighting wars. The other two claims are true, but with caveats. First, the "militia model" may be more folklore than reality: For most of American history, the active component or (more often), short-term draftees or volunteers — not the organized militia — provided the bulk of American combat power. Still, the militia and Guard served admirably in a variety of capacities throughout American history, responding to trouble at home and, more lately, to crises abroad. Second, and perhaps profoundly, while it has reflected many of the citizen-soldier traits throughout its centuries of existence the National Guard-except for a brief period at the earliest militia period - never embodied all four traits of the citizen-soldier ideal.

Table 3. Assessment of the Claims About the National Guard

\begin{tabular}{l|c|c|c|c|c} 
& Claim & $\begin{array}{c}\text { The Militia } \\
\text { Period } \\
\text { (Founding-1830) }\end{array}$ & $\begin{array}{c}\text { The Volunteer } \\
\text { Period } \\
(\mathbf{1 8 3 1 - 1 9 0 2 )}\end{array}$ & $\begin{array}{c}\text { Strategic } \\
\text { Reserve } \\
(\mathbf{1 9 0 3 - 1 9 9 0 )}\end{array}$ & $\begin{array}{c}\text { Operational Reserve } \\
\text { (1991-Present) }\end{array}$ \\
\hline \multirow{3}{*}{ Historical } & $\begin{array}{c}\text { Principal instrument } \\
\text { of U.S. security }\end{array}$ & True & False & More true & More true \\
\cline { 2 - 6 } & $\begin{array}{c}\text { Prevented the } \\
\text { United States from } \\
\text { fighting wars }\end{array}$ & False & False & False & False \\
\hline \multirow{3}{*}{$\begin{array}{l}\text { Sociological } \\
\text { (Citizen soldier) }\end{array}$} & Obligatory & True (on paper) & Less true & Less true & False \\
\cline { 2 - 6 } & Universal & True & True & Less true & Less true \\
\cline { 2 - 6 } & Legitimate & True & True & True & True \\
\cline { 2 - 6 }
\end{tabular}

On a deeper level, however, the National Guard's evolution tells a nuanced and more important story (see Table 4). Long before the term "operational reserve," the National Guard embarked on a series of reforms to become a more proficient, responsive force. While it never became the United States' principal warfighting force, the Guard today increasingly shoulders more of the burden. But this evolution has not been cost-free. The Guard's ability to check federal power in the manner the framers of the Constitution had originally envisioned the militia - which was never absolute to begin with - has increasingly fallen by the wayside, as military and legal reforms strengthened federal control over the Guard. More important, as the Guard has grown more militarily capable, it has become less like the militia of the founding era-manned by fewer true civilians and representing a narrower segment of American society. 
In sum, today's Guard looks more like professionals and less like the classic concept of citizen soldiers.

Table 4. Trends in the Citizen Soldier Construct

\begin{tabular}{l|l|l} 
& Claim & The Verdict \\
\hline \multirow{3}{*}{ Historical } & Principal instrument of U.S. security & Increasingly true \\
\cline { 2 - 3 } & Prevented the United States from fighting wars & Not true \\
\hline \multirow{4}{*}{$\begin{array}{l}\text { Sociological } \\
\text { (Citizen soldier) }\end{array}$} & Obligatory & Increasingly less true \\
\cline { 2 - 3 } & Universal & Increasingly less true \\
\cline { 2 - 3 } & Legitimate & True \\
\cline { 2 - 3 } & Civilian & Increasingly less true
\end{tabular}

These competing trends hint at a fundamental and perhaps irreconcilable tension among these three claims. To provide a useful military tool for American national security, a military force needs to be both readily deployable and militarily proficient. Being readily deployable requires minimizing the same obstacles that would constrain U.S. ability to fight wars. Less obviously, perhaps, maintaining military proficiency requires a more professional force, with fewer true citizen soldiers, as warfare grows more intricate and demands more-specialized skills that must be honed continuously. In sum, an oxymoron may be embedded in some of the rhetoric about the Guard: In this day and age, a force cannot simultaneously be the principal instrument of American national security, a check on federal power, and composed of citizen soldiers.

What should this mean for today's policy fights between the active component and the National Guard? At the end of the day, shifting to a Guard-heavy force may be a prudent policy choice for economic and utilitarian reasons. These decisions, however, should be considered dispassionately - without the romanticized version of history and citizen soldiers that often clouds discussions of the active-reserve balance. The National Guard is certainly not alone in having a certain seductive appeal. Airpower today has its own mystique, as do Special Operations Forces. ${ }^{1}$ At other points in American military history, the horse cavalry, the paratroopers, and the armor corps had similar mystique-based partly on truth and partly on lore. Arguably, these auras help give military service its character. And yet, these heroic narratives can prove debilitating if they prevent objective examination of capabilities and clear analysis of limitations. As budget battles are decided, we need to demystify the citizen soldier and see them for who they are, not what we imagine them to be.

${ }^{1}$ Eliot A. Cohen, “The Mystique of U.S. Airpower,” Foreign Affairs, Vol. 73, No. 1, February 1994, pp. 109-124. 


\section{References}

Adams, David, "Internal Military Intervention in the United States," Journal of Peace Research, Vol. 32, No. 2, 1995, pp. 197-211.

Adams, Noah, "Shots Still Reverberate for Survivors of Kent State," National Public Radio, May 3, 2010. As of October 15, 2014:

http://www.npr.org/templates/story/story.php?storyId=126423778

Adjutant General's Office, Statistical Exhibit of Strength of Volunteer Forces Called Into Service During the War With Spain; with Losses From All Causes, Washington, D.C.: Government Printing Office, 1899; reprinted online by the U.S. Army Center of Military History Historical Resources Branch, Spanish-American War: Volunteer Forces, undated.

Air National Guard, ANG Heritage: Missions, Wars and Operations, undated.

Beardsley, Steven, “Active-Duty Troops to Deploy to Kosovo for First Time in a Decade," Stars and Stripes, March 13, 2013. As of October 6, 2014:

http://www.stripes.com/news/active-duty-troops-to-deploy-to-kosovo-for-first-time-in-adecade-1.211663

Brauner, Marygail K., and Glenn A. Gotz, Manning Full-Time Positions in Support of the Selected Reserve, Santa Monica, Calif.: RAND Corporation, R-4034-RA, 1991. As of November 21, 2014:

http://www.rand.org/pubs/reports/R4034.html

Brayton, Abbott A., "American Reserve Policies Since World War II," Military Affairs, Vol. 36, No. 4, December 1972, pp. 139-144.

Buchalter Alice R., and Seth Elan, Historical Attempts to Reorganize the Reserve Components, Washington, D.C.: Federal Research Division, Library of Congress, October 2007. As of June 8, 2015:

https://www.loc.gov/rr/frd/pdf-files/CNGR_Reorganization-Reserve-Components.pdf

Campbell, James, “The National Guard as a Strategic Hedge," Parameters, Vol. 44, No. 1, Spring 2014, pp. 95-106.

Cantor, Louis, "Elihu Root and the National Guard: Friend or Foe?" Military Affairs, Vol. 33, No. 3, December 1969, pp. 361-373.

Clark, Charles Sydney, "The Future of the National Guard," The North American Review, Vol. 170, No. 522, May 1900, pp. 730-744. 
Center for Military History, War in the Persian Gulf: Operations Desert Shield and Desert Storm August 1990-March 1991, Washington, D.C.: Center for Military History, 2010.

Coffman, Edward M., The Old Army: A Portrait of the American Army in Peacetime, 17841898, New York: Oxford University Press, 1986.

Cohen, Eliot A., "Constraints on America's Conduct of Small Wars," International Security, Vol. 9, No. 2, Fall 1984, pp. 151-181.

_ , "The Mystique of U.S. Airpower," Foreign Affairs, Vol. 73, No. 1, February 1994, pp. 109-124.

—_, "Twilight of the Citizen-Soldier," Parameters, Summer 2001, pp. 23-28.

Colby, Elbridge, and James F. Glass, "The Legal Status of the National Guard," The Virginia Law Review, Vol. 29, No. 7, May 1943, pp. 839-856.

Commission on the National Guard and Reserves, Transforming the National Guard and Reserves into a 21st-Century Operational Force, final report to Congress and the Secretary of Defense, January 31, 2008. As of November 21, 2014: http://www.loc.gov/rr/frd/pdf-files/CNGR_final-report.pdf

Cosmas, Graham A., An Army for Empire: The United States Army in the Spanish-American War, College Station, Texas: Texas A\&M University Press, 1998.

Cunliffe, Marcus, Soldiers and Civilians: The Martial Spirit in America 1775-1865, Boston, Mass.: Little, Brown and Company, 1968.

Dao, James, "Air National Guard Lobbies Successfully Against Budget Cuts," New York Times, April 24, 2012. As of August 21, 2014 :

http://www.nytimes.com/2012/04/24/us/air-national-guard-lobbies-successfully-againstbudget-cuts.html?_r=0

"Death Toll Rises for U.S. Reservists in Iraq," USA Today, October 10, 2005. As of August 21, 2014:

http://usatoday30.usatoday.com/news/nation/2005-10-10-reservestoll_x.htm

Derthick, Martha, The National Guard in Politics, Cambridge, Mass.: Harvard University Press, 1965.

Dobbs, Michael, "Democrat Says He Helped Bush into Guard to Score Points," Washington Post, September 4, 2004. As of October 15, 2014: http://www.washingtonpost.com/wp-dyn/articles/A60319-2004Sep3.html

Doubler, Michael D. I Am the Guard: A History of the Army National Guard, 1636-2000, Department of the Army, 2001. 
- The National Guard and Reserve: A Reference Handbook, Westport, Conn.: Praeger Security International, 2008.

Esch, John J., "Our Second Line-The National Guard," The North American Review, Vol. 177, No. 561, August 1903, pp. 288-296.

Everstine, Brian, "Guard Compromise Not Enough for Lawmakers," Air Force Times, April 24, 2012. As of August 21, 2014:

http://www.airforcetimes.com/article/20120424/NEWS/204240304/Guard-compromise-notenough-lawmakers

Fogleman, Ronald R. "Fundamental to Military Tradition: America, Militia Nation," speech to the National Guard Association of the United States Convention, Cleveland, Ohio, September 7, 1995.

—_ "Going Back to the Future: Militia Model Could Cut U.S. Expenditures," Defense News, January 16, 2012. As of January 27, 2015:

http://archive.defensenews.com/article/20120116/DEFFEAT05/301160015/Going-BackFuture

Freedberg, Sydney, Jr., "Budgets and 'Betrayal': National Guard Fights to Keep Apache Gunships," Breaking Defense, January 23, 2014a. As of September 11, 2014:

http://breakingdefense.com/2014/01/budgets-betrayal-national-guard-fights-to-keep-apachegunships

_- "National Guard Commanders Rise in Revolt Against Active Army; MG Rossi

Questions Guard Combat Role," Breaking Defense, March 11, 2014b. As of August 21, 2014:

http://breakingdefense.com/2014/03/national-guard-commanders-rise-in-revolt-againstactive-army-mg-ross-questions-guard-combat-role

Gallup, Military and National Defense, undated. As of October 6, 2014:

http://www.gallup.com/poll/1666/military-national-defense.aspx

Government Accountability Office, National Guard: Peacetime Training Did Not Adequately

Prepare Combat Brigades for Gulf War, Washington, D.C., GAO/NSIAD-91-263, September 24, 1991. As of June 8, 2015:

http://www.gao.gov/assets/160/151085.pdf

— Army Training: Replacement Brigades Were More Proficient Than Guard Roundout Brigades, Washington, D.C., GAO/NSIAD-93-4, November 1992. As of June 8, 2015:

http://www.gao.gov/assets/220/217240.pdf 
Grady, John, "What a Difference Two Wars Make: No Battles Between Army, Guard and Reserve," Breaking Defense, April 2, 2012. As of August 21, 2014:

http://breakingdefense.com/2012/04/what-a-difference-two-wars-make-no-battles-betweenarmy-guard

Grass, Frank J., “Army Total Force Mix," statement before the Senate Armed Services Committee, April 8, 2014. As of August 23, 2014:

http://www.armed-services.senate.gov/imo/media/doc/Grass_04-08-14.pdf

Griffith, James, "Being a Reserve Soldier: A Matter of Social Identity," Armed Forces and Society, Vol. 36, No. 1, October 2009, pp. 38-64.

_- "Reserve Identities: What Are They? And Do They Matter? An Empirical Examination," Armed Forces and Society, Vol. 37, No. 4, October 2011, pp. 619-635.

Gross, Charles J., "The Air National Guard: Past, Present, and Future Prospects," Airpower Journal, Winter 1996, pp. 59-69.

Guensburg, Carol, "National Guard Deployments for Civil Unrest Uncommon in U.S.," Voice of America, August 18, 2014. As of September 9, 2014:

http://www.voanews.com/content/national-guard-deployments-for-civil-unrest-fergusonmissouri/2417956.html

Hagel, Chuck, U.S. Secretary of Defense, “FY15 Budget Preview,” press briefing, February 24, 2014.

Hargett, Gus, President, National Guard Association of the United States, testimony delivered before the Reserve Forces Policy Board's Task Group, July 16, 2013. As of August 20, 2014: http://www.ngaus.org/sites/default/files/Hargett\%20Oral\%20Testimony_RFPB.pdf

Heller, Charles E., The New Military Strategy and Its Impact on the Reserve Component, Carlisle, Pa.: Strategic Studies Institute, United States Army War College, 1991.

Hill, Jim Dan, The Minute Man in Peace and War: A History of the National Guard. Harrisburg, Pa.: The Stackpole Company, 1964.

Hostli, Ole R., "Of Chasms and Convergences: Attitudes and Beliefs of Civilians and Military Elites at the Start of a New Millennium," in Peter D. Feaver and Richard H. Kohn, eds., Soldiers and Civilians: The Civil-Military Gap and American National Security, Cambridge, Mass.: MIT Press, 2001.

Ingram, William E., Jr., "The Army National Guard: Where We've Been and Where We Want to Go," Army, August 2012, pp. 25-28.

Janowitz, Morris, “The Citizen Soldier and National Service," Air University Review, December 1979. 
Kapp, Lawrence, and Barbara Salazar Torreon, Reserve Component Personnel Issues: Questions and Answers, Washington, D.C.: Congressional Research Service, RL30802, June 13, 2014. As of August 24, 2014:

http://fas.org/sgp/crs/natsec/RL30802.pdf

Karnow, Stanley, Vietnam: A History, New York: Viking Press, 1983.

Kester, John G., "State Governors and the Federal National Guard," Harvard Journal of Law and Public Policy, Vol. 11, No. 1, 1988, pp. 177-179.

King, David C., and Zachary Karabell, The Generation of Trust: Public Confidence in the U.S. Military since Vietnam, Washington, D.C.: AEI Press, 2003.

Klimas, Joshua, Richard E. Darilek, Caroline Baxter, James Dryden, Thomas F. Lippiatt, Laurie L. McDonald, J. Michael Polich, Jerry M. Sollinger, and Stephen Watts, Assessing the Army's Active-Reserve Component Force Mix, Santa Monica, Calif.: RAND Corporation, RR-417-1-A, 2014. As of November 21, 2014: http://www.rand.org/pubs/research_reports/RR417-1.html

Kohn, Richard H., Eagle and Sword: The Federalists and the Creation of the Military Establishment in America, 1783-1802, New York: The Free Press, 1975.

— , "Using the Military at Home: Yesterday, Today, and Tomorrow," Chicago Journal of International Law, Vol. 4, No. 1, 2003, pp. 165-192.

Krebs, Ronald R., "The Citizen-Soldier Tradition in the United States: Has Its Demise Been Greatly Exaggerated?" Armed Forces \& Society, Vol. 36, No. 1, 2009, pp. 153-174.

Kreidberg, Marvin A. and Merton G. Henry, History Of Military Mobilization in the United States Army 1775-1945, Washington, D.C.: Department of the Army, 1955.

Laird, Melvin R. "Iraq: Learning the Lessons of Vietnam," Foreign Affairs, Vol. 84, No. 6, November-December 2005, pp. 23-43

Lawrence, Stewart J., "The Unquiet Ghosts of Kent State," The Guardian, May 4, 2011. As of February 25, 2015:

http://www.theguardian.com/commentisfree/cifamerica/2011/may/04/vietnam-us-military

Lyle, Amaani, "Air Force Secretary Reports on Total Force Balance," American Forces Press Service, April 30, 2014.

Mahon, John K., History of the Militia and the National Guard, New York: MacMillan, 1983.

Melnyk, Les', Mobilizing for the Storm: The Army National Guard in Operation Desert Shield and Desert Storm, National Guard Bureau Office of Public Affairs Historical Services Division, 2001. 
Meyer, Mark P., The National Guard Citizen-Soldier: The Linkage between Responsible National Security Policy and the Will of the People, Maxwell Air Force Base, Ala.: Air War College, Maxwell Paper No. 6, November 1996.

Moskos, Charles, “A New Concept of the Citizen-Soldier," Orbis, 2005, pp. 664-676.

Myers, Richard, Chairman, Joint Chiefs of Staff, “A Note from the Chairman," Joint Forces Quarterly, Vol. 36, 2004, pp. 1-10.

Nagl, John, and Travis Sharp, An Indispensable Force: Investing in America's National Guard and Reserves, Washington, D.C.: Center for a New American Security, September 2010.

National Guard, About the Army National Guard, undated.

National Guard Association of the United States, "FY15 Fact Sheet: Ground Based and Airborne Sense and Avoid Capability for ANG Remotely Piloted Aircraft," undated-a. As of June 10, 2015: http://www.ngaus.org/sites/default/files/FY15\%20GBSA\%20RPA.pdf

- Legislative Strategic Plan, $113^{\text {th }}$ Congress, undated-b. As of July 2, 2015: http://www.ngaus.org/sites/default/files/NGAUSStrategicPlan.pdf

National Guard Bureau, 2015 National Guard Bureau Posture Statement, Washington, D.C., 2015.

Office of the Deputy Assistant Secretary of Defense for Military Community and Family Policy, 2012 Demographics: Profile of the Military Community, undated.

Pew Foundation, "The Military-Civilian Gap: Fewer Family Connections," November 23, 2011. As of September 8, 2014:

http://www.pewsocialtrends.org/2011/11/23/the-military-civilian-gap-fewer-familyconnections

__, "Public Esteem for Military Still High,” July 11, 2013. As of November 21, 2014: http://www.pewforum.org/2013/07/11/public-esteem-for-military-still-high

Rainey, James W., "The Questionable Training of the AEF in World War I," Parameters, 1992, pp. 89-103.

Reserve Forces Policy Board, "Eliminating Major Gaps in DoD Data on the Fully-Burdened and Life-Cycle Cost of Military Personnel: Cost Elements Should be Mandated by Policy," Falls Church, Va., January 14, 2013. As of August 20, 2014: http://rfpb.defense.gov/Portals/67/Documents/RFPB_Report_13-01_Operational_ Reserve_web.pdf 
Robbert, Albert A., Costs of Flying Units in Air Force Active and Reserve Components, Santa Monica, Calif.: RAND Corporation, TR-1275-AF, 2013. As of November 21, 2014: http://www.rand.org/pubs/technical_reports/TR1275.html

Robbert, Albert A. James H. Bigelow, John E. Boon, Jr., Lisa M. Harrington, Michael McGee, S. Craig Moore, Daniel M. Norton, William W. Taylor, Suitability of Missions for the Air Force Reserve Components, Santa Monica, Calif.: RAND Corporation, RR-429, 2014. As of March 17, 2015: http://www.rand.org/pubs/research_reports/RR429.html

Romano, John F., "State Militias and the United States: Changed Responsibilities for a New Era," The Air Force Law Review, Vol. 56, 2005, pp. 233-247

Rosenfeld, Susan, and Charles J. Gross, Air National Guard at 60: A History, Washington D.C., Air National Guard, 2007.

Schandler, Herbert Y., The Unmaking of a President: Lyndon Johnson and the Vietnam War, Princeton, N.J.: Princeton University Press, 1977.

Schmidt, William E., "Some Now in Congress Joined Reserve or Guard," New York Times, 1988. As of October 15, 2014:

http://www.nytimes.com/1988/08/20/us/some-now-in-congress-joined-reserve-or-guard.html

Segal, David R., and Ronald B. Tiggle, "Attitudes of Citizen-Soldiers Toward Military Missions in the Post-Cold War World," Armed Forces and Society, Vol. 23, No. 3, 1997, pp. 373-390.

Shanker, Thom, and Helene Cooper, "Pentagon Plans to Shrink Army to Pre-World War II Level," New York Times, February 23, 2014. As of September 10, 2014: http://www.nytimes.com/2014/02/24/us/politics/pentagon-plans-to-shrink-army-to-preworld-war-ii-level.html?_r=0

Shy, John, A People Numerous and Armed: Reflections on the Military Struggle for the American Independence, Revised Edition, Ann Arbor, Mich.: University of Michigan Press, 1990.

Strauss, Barry, "Reflections on the Citizen-Soldier,” Parameters, 2003, pp. 66-75.

Stuckey, John D., and Joseph H. Pistorius, "Mobilization for the Vietnam War: A Political and Military Catastrophe," Parameters, Vol. 15, No. 1, 1985, pp. 26-38.

Todd, Frederick P., "Our National Guard: An Introduction to Its History," Military Affairs, Vol. 5, No. 3, 1941, pp. 142-170.

U.S. Constitution, Article I, Section 8, Clause 15: Militia. As of June 30, 2015 : http://www.archives.gov/exhibits/charters/constitution_transcript.html 
U.S. Department of Defense, Quadrennial Defense Review 2014, Washington, D.C., March 4, 2014.

—_, "Reserve Components, Unique SSAN Activations," February 10, 2015.

U.S. Marine Corps, Small Wars Manual, Washington, D.C.: Government Printing Office, 1940. , Our Purpose, undated. As of April 16, 2015: http://www.marines.com/history-heritage/our-purpose

Verga, Peter, "Transformation of the Reserve Component," in Threats at Our Threshold, Washington, D.C.: Center for Strategic and International Studies, 2006. As of March 18, 2015:

http://csis.org/programs/homeland-security-program/threats-our-threshold/2006-conference

Vest, Bonnie M., "Citizen, Soldier, or Citizen-Soldier? Negotiating Identity in the US National Guard," Armed Forces \& Society, Vol. 39, No. 4, October 2013, pp. 602-662.

Virginia Military Institute, Citizen-Soldier, undated. As of January 28, 2015: http://admissions.vmi.edu/experience/citizen-soldiers

Waterhouse, Michael, and JoAnne O’Bryant, "National Guard Personnel and Deployments: Fact Sheet," Washington, D.C.: Congressional Research Service, May 1, 2008. 
The National Guard is often portrayed as the modern heir to the colonial militia and as retaining at least three of the latter's defining attributes-a key instrument of American national security, a check on federal power, and home of today's "citizen soldiers." This report explores how the term citizen soldier has been defined in academic literature-as compulsory, universal, legitimate service by civilians-and then looks at how the National Guard has evinced these attributes at various periods in its history. Since the United States' founding, the militia-and later, the National Guard-slowly evolved into an increasingly formidable warfighting force and increasingly important tool for national security. This evolution, however, has come at the expense of two other attributes of the colonial militiaserving as a check on federal power and filling its ranks with citizen soldiers. The report concludes that there are inherent and increasing tensions among being a warfighting force, serving as a check on federal power, and embodying the ideals of a citizen soldier, and it is not clear that the Guard-or any other force for that matter-can fully reconcile them. Ultimately, the Guard's transformation from citizen soldiers to a professional force may very well be inevitable and is likely a positive development for American national security. It is, however, important to realize that this trend is occurring, to demystify the citizen soldier, and to see the force for what it is. 